\title{
Three Serotonin Responses in Cultured Mouse Hippocampal and Striatal Neurons
}

\author{
Jerrel L. Yakel, Laurence O. Trussell, ${ }^{a}$ and Meyer B. Jackson \\ Department of Biology, University of California, Los Angeles, Los Angeles, California 90024
}

Serotonin (5-HT) produced 3 different types of responses in neurons of mouse hippocampal and striatal cell cultures. These 3 responses have been characterized in terms of their pharmacological specificity, physiological mechanism, and dependence on cytoplasmic components. The most frequently observed response was inhibitory and was the result of a receptor-mediated activation of an inwardly rectifying potassium conductance. Typically, the response peaked within 1-3 sec of agonist application and did not exhibit desensitization. 5-Methoxy- $\mathbf{N}, \mathbf{N}$-dimethyltryptamine also produced this response in both striatal and hippocampal cultures and had no effect on the other 5-HT currents observed in this study. The selective 5-HT agonists-8-hydroxy-2-(di-n-propylamino)-tetralin, 1-(m-chlorophenyl) piperazine, and 1-(2-methoxyphenyl) piperazine-did not activate this outward current response. Methysergide did not block the 5-HT-activated outward current and often acted as an agonist. The response was lost in low-series-resistance recordings which facilitate solution exchange between the patch electrode and the cell. The loss of this response was prevented by using high-resistance patch electrodes, which retard this exchange. The 2 other responses described in this study were excitatory. They were seen less often than the inhibitory response. One of the excitatory responses was fast, with a time to peak of approximately $200 \mathrm{msec}$ and a duration of 2-4 sec. The other was slow, with a time to peak of 7-10 sec and a duration of approximately 30-40 sec. Both of these responses were accompanied by a conductance increase. The fast excitatory response reversed at depolarized potentials and desensitized with a rate that varied with voltage. Metoclopramide and $d$-tubocurarine completely and reversibly blocked this fast excitatory response, while methysergide had no effect. The fast excitatory response was not lost during intracellular dialysis of cells in cultures from either striatum or hippocampus. In cultures from both brain regions, the slow excitatory response was blocked by methysergide. The slow excitatory response was lost even in patch-clamp recordings

\footnotetext{
Received Mar. 13, 1987; revised Sept. 29, 1987; accepted Sept. 29, 1987.

We thank Huda Detlefs and Linda Attardo-Paczkowski for preparing cell cultures used in this study. This work was supported by NIH Grants HD5958 and NS21908.

Correspondence should be addressed to Meyer B. Jackson, Department of Biology, UCLA, 405 Hilgard Avenue, Los Angeles, CA 90024.

a Present address: Washington University School of Medicine, Department of Anatomy and Neurobiology, 660 South Euclid Avenue, St. Louis, MO 63110.

Copyright $@ 1988$ Society for Neuroscience $0270-6474 / 88 / 041273-13 \$ 02.00 / 0$
}

with high-resistance electrodes. This response was similar to responses to dopamine, norepinephrine, and forskolin, all of which are known to activate adenylate cyclase in the CNS.

Serotonin (5-HT) is generally believed to act as a neurotransmitter or neuromodulator in a variety of invertebrate and vertebrate species (Steinbusch and Nieuwenhuys, 1979; Steinbusch, 1981). A multiplicity of responses to 5-HT have been observed in invertebrate preparations (Gerschenfeld and Paupardin-Tritsch, 1974). Both inhibitory and excitatory responses to 5-HT have been reported in many mammalian CNS preparations (see review by VanderMaelen, 1985). Inhibitory responses have been observed in the dorsal raphe nucleus (Aghajanian and Lakoski, 1984), rat dorsal lateral geniculate (Rogawski and Aghajanian, 1980), rat hippocampus (Segal, 1980; Andrade et al., 1986), guinea pig hippocampus (Jahnsen, 1980), and striatum from rabbit (Herz and Zieglgänsberger, 1968) and rat (Bcvan et al., 1975; Davies and Tongroach, 1978). A proposed mechanism for the inhibitory effect is an increase in potassium conductance (Jahnsen, 1980; Segal, 1980; Aghajanian and Lakoski, 1984; Andrade et al., 1986).

Excitatory responses to 5-HT have been observed in a variety of CNS regions, including the guinea pig hippocampus (Jahnsen, 1980), rat neostriatum (Bevan et al., 1975; Park et al., 1982), rat facial motoneurons (VanderMaelen and Aghajanian, 1982), and cultured mouse spinal cord (Cottrell and Green, 1982). In facial motoneurons the excitatory response is associated with a decrease in potassium conductance (VanderMaelen and Aghajanian, 1982). In hippocampal pyramidal neurons, 5-HT decreases the conductance of the membrane, but the ion selectivity of this conductance change is unknown (Jahnsen, 1980). 5-HT has a variety of effects on many PNS tissues as well. Various ionic mechanisms have been proposed for these actions (VanderMaelen, 1985).

The largest concentration of 5-HT-containing neurons in the mammalian CNS is found in the raphe nuclei, with especially high levels in the dorsal raphe nucleus (Dahlström and Fuxe, 1964). These serotonergic raphe nuclei project to most regions of the mammalian CNS, including the striatum (Graybiel and Ragsdalc, 1979) and hippocampus (Walaas, 1983). The second largest aminergic projection of neurons into the striatum arises from the dorsal raphe nucleus (Anden et al., 1964; Dahlström and Fuxe, 1964); in the rat, approximately $80 \%$ of these dorsal raphe neurons are serotonergic (Steinbusch et al., 1981). There is also a large projection of neurons from the various raphe nuclei into the hippocampus, arising mainly from the median raphe nucleus (Azmitia and Segal, 1978); in the cat, approximately $35 \%$ of these median raphe neurons are serotonergic 
(Wiklund et al., 1981). Consistent with the presence of serotonergic projections, the striatum (Enna et al., 1977; Peroutka and Snyder, 1981; Leysen, 1985) and the hippocampus (Enna et al., 1977; Leysen, 1985) contain a high density of 5-HT binding sites.

These well-defined serotonergic pathways from the median and dorsal raphe nuclei suggest that the hippocampus and striatum are important loci for the study of 5-HT physiology and pharmacology. In order to gain insight into the biophysical mechanisms underlying the 5-HT responses in the hippocampus and striatum, we have used patch-clamp techniques (Hamill et al., 1981) to study the effects of 5-HT on the membrane electrical properties of dissociated embryonic mouse hippocampal and striatal neurons in culture. Using these techniques, we find that neurons cultured from either striatum or hippocampus exhibit 3 distinctly different responses to 5-HT (Yakel et al., 1986). In this study, we present some of the physiological and pharmacological characteristics of these responses.

\section{Materials and Methods}

The methods used in this study were similar to those in a previous study from this laboratory of adenosine responses in striatal neurons (Trussell and Jackson, 1985). The culturing procedure was adapted from a procedure originally designed for culturing of mouse cortex (Swaiman et al., 1982). The hippocampal or striatal tissue was removed from mouse embryos in the 17 th or 18 th day of gestation, treated for $30 \mathrm{~min}$ with $0.25 \%$ trypsin in calcium-free saline, and then triturated. The cells were plated on $35 \mathrm{~mm}$ Primaria culture dishes (Falcon) in minimal essential medium (MEM) with 10\% each of horse serum and fetal calf serum. After $5 \mathrm{~d}$, the cells were changed into MEM with $10 \%$ horse serum, $10 \mu \mathrm{M}$ fluorodeoxyuridine, and $50 \mu \mathrm{M}$ uridine. Two days later, the cells were changed into MEM and $10 \%$ horse serum (without fluorodeoxyuridine and uridine); subsequently, they were changed twice weekly into the same medium. The cultures were generally used 1-5 weeks after plating.

During the electrophysiological recordings, the cells were usually maintained at $34-35^{\circ} \mathrm{C}$ in a solution containing $140 \mathrm{~mm} \mathrm{NaCl}, 4 \mathrm{mM}$ $\mathrm{KCl}, 2 \mathrm{mM} \mathrm{CaCl}_{2}, 1 \mathrm{mM} \mathrm{MgCl}_{2}$, and $10 \mathrm{~mm}$ glucose, buffered at $\mathrm{pH} 7.2$ with $10 \mathrm{mM}$ HEPES $\left(N\right.$-2-hydroxyethylpiperazine- $N^{\prime}-2$-ethanesulfonic acid). A few recordings were carried out at room temperature $\left(22-24^{\circ} \mathrm{C}\right)$. Unless otherwise specified, $0.5 \mu \mathrm{M}$ TTX was added to the bathing solution to block action potentials. The electrode filling solution contained $140 \mathrm{~mm}$ potassium gluconate, $0.5 \mathrm{mM} \mathrm{CaCl}_{2}, 1 \mathrm{mM} \mathrm{MgCl}$, and $5 \mathrm{~mm}$ EGTA (ethylene glycol-bis $\left(\beta\right.$-amino ethyl ether) $N, N, N^{\prime}, N^{\prime}$-tetraacetic acid) buffered at $\mathrm{pH} 7.2$ with $10 \mathrm{~mm}$ HEPES. In some recordings, 47 mM potassium citrate and $93 \mathrm{~mm}$ sucrose replaced $140 \mathrm{~mm}$ potassium gluconate. BAPTA [tetra potassium 1,2-bis(2-aminophenoxy)-ethane$N, N, N^{\prime}, N^{\prime}$-tetraacetate] (Tsien, 1980) was used in later experiments as a calcium buffer in place of EGTA. When BAPTA was used, the composition of the filling solution was $120 \mathrm{~mm}$ potassium gluconate, 0.5 $\mathrm{mM} \mathrm{CaCl}_{2}, 1 \mathrm{mM} \mathrm{MgCl}_{2}, 5 \mathrm{~mm}$ BAPTA, and $20 \mathrm{~mm}$ sucrose to balance the osmolarity. The $\mathrm{pH}$ of these solutions was adjusted with $\mathrm{KOH}$, which results in the clevation of the potassium ion concentration by 14 mM for the EGTA solutions and $5 \mathrm{~mm}$ for the BAPTA solutions. There were no significant differences between recordings made with electrode filling solutions containing either BAPTA or EGTA; the computed free calcium ion concentration was $1.1 \times 10^{-8} \mathrm{M}$ with BAPTA and $2.2 \times$ $10^{-8} \mathrm{M}$ with EGTA.

In ion replacement experiments, the potassium concentration in the bathing solution was raised by replacing sodium with potassium, without affecting anion concentrations. The intracellular chloride concentration was raised by replacing gluconate with chloride, without affecting cation concentrations.

An EPC.-7 patch-clamp amplifier (List Electronics/Medical Systems) was used to voltage- or current-clamp the cultured neurons in the tightseal, whole-cell recording configuration (Hamill et al., 1981; Marty and Neher, 1983). Signals were recorded on a Gould chart recorder. The series resistance (the resistance through the pipette into the cell) was determined either by examining the shape of the capacitive transient in response to a voltage-clamp pulse (Marty and Neher, 1983) or from the ohmic component of the voltage response to a current-clamp pulse.
Patch electrodes were fabricated from 3 different types of glass (Garner Glass Co., Claremont, CA). Aluminosilicate glass (Corning 1720; 0.9 $\mathrm{mm}$ I.D., $1.2 \mathrm{~mm}$ O.D.) electrodes had resistances ranging from 1.5 to $5 \mathrm{M} \Omega$. In intracellular recordings with these electrodes, series resistances ranged from 8 and $25 \mathrm{M \Omega}$. Kovar sealing glass (Corning 7052;0.9 mm I.D., $1.2 \mathrm{~mm}$ O.D.) electrodes had resistances ranging from 3 to $6 \mathrm{M} \Omega$, with series resistances ranging from 10 to $35 \mathrm{M} \Omega$. Thick-walled borosilicate glass (Corning KG-33; $0.6 \mathrm{~mm}$ I.D., $1.2 \mathrm{~mm} \mathrm{O.D.)} \mathrm{electrodes}$ had resistances ranging from 8 to $25 \mathrm{M} \Omega$, with series resistances ranging from 50 and $150 \mathrm{M} \Omega$. The high-resistance borosilicate electrodes were occasionally used in place of low-resistance electrodes fabricated from the 2 other types of glass for several reasons, including (1) a higher success rate of $\mathrm{G} \Omega$ seal formation, (2) more stable recordings, (3) lower electrical noise, and (4) a lower rate of intracellular dialysis, i.e., solution exchange between the electrode and the cell (Marty and Neher, 1983).

5-HT responses recorded with high-resistance electrodes were qualitatively identical to responses observed with low-resistance electrodes. The major drawback with the recordings obtained with the thick-walled borosilicate electrodes was the inability to adjust precisely the membrane holding potential. With high-resistance electrodes the series resistance correction to the holding potential is very small (only 1 or 2 $\mathrm{mV}$ ), as long as the holding potential is within $5 \mathrm{mV}$ of the resting membrane potential. Therefore, the potential was held at $-70 \mathrm{mV}$ in many of the recordings employing high-resistance borosilicate electrodes. When the current-voltage relationships of the 5-HT responses reported in this study were determined, low-resistance electrodes were used to minimize the voltage correction for the series resistance. The current-voltage curves reported in Results were generated from recordings where the series resistance correction was never larger than $5 \mathrm{mV}$. In addition, the voltages were also corrected for a $10 \mathrm{mV}$ junction potential that appeared between the bathing solution and the patch electrode filling solution when the major anion in the patch electrode was either gluconate or citrate. The adequacy of the voltage clamp, even during 5-HT responses, was demonstrated by the similarity of the 5-HT outward current reversal potential with the expected reversal potential for potassium currents (Fig. 5).

The neurons were not effectively space-clamped. Even when lowresistance electrodes were used, sodium and calcium spikes always escaped the clamp. This is most likely due to the excitable membrane of the neurites that are a large electrotonic distance from the soma. In addition, the time constants of the capacitive transients observed with $10 \mathrm{mV}$ pulses were approximately $5 \mathrm{msec}$ in duration for intracellular recordings using low-resistance electrodes (with series resistances of approximately $15 \mathrm{M} \Omega$ ) and 10 to $20 \mathrm{msec}$ for recordings using highresistance electrodes (with series resistances of $50 \mathrm{M} \Omega$ or higher). However, the 5-HT-activated currents were slower and generally weaker than the regenerative currents. The fastest 5-HT responses generally peak in $100-200 \mathrm{msec}$. Thus, even the fastest responses were longer than the capacitive transients observed with high-resistance electrodes. Therefore, the voltage clamp was fast enough to follow the responses.

Current-voltage curves were obtained by holding the membrane potential constant for at least $5 \mathrm{sec}$ before 5-HT application; the peak of the 5-HT-activated current was then plotted versus the holding potential. Responses were tested periodically at $-70 \mathrm{mV}$ throughout an experiment to monitor the responsiveness of a cell and to provide assurance that there were no changes as a result of intracellular dialysis. If the control response had declined by more than $10 \%$, studics of the voltage dependence were stopped.

The average resting potential of the hippocampal neurons was $-62 \pm$ $6 \mathrm{mV}$ (mean $\pm \mathrm{SD}, n=129$ cells), and the average resting potential of the striatal neurons was $-64 \pm 6 \mathrm{mV}$ (mean $\pm \mathrm{SD}, n=93$ cells). The cell input resistances were extremely variable, ranging from 63 to 667 $\mathrm{M} \Omega$ for hippocampal neurons and 77 to $1000 \mathrm{M} \Omega$ for striatal neurons. This difference was probably due to the smaller average size of striatal neurons relative to hippocampal neurons. Cell size tended to increase with culture age, and cells in younger cultures usually had higher input resistances than cells in older cultures.

The neurons studied here were morphologically similar to neurons of rat striatal (Panula et al., 1979) and mouse hippocampal (Peacock et al., 1979) cultures described by others. Striatal cultures had predominantly small $(\sim 10-14 \mu \mathrm{m})$, round, phase-bright neurons, with a few larger more extended neurons. We recorded mostly, but not exclusively, from the small round neurons. Hippocampal cultures included larger $(\sim 15-20 \mu \mathrm{m})$ phase-bright neurons with apparent pyramidal morphology along with cells of diverse morphology. We recorded mostly, but 

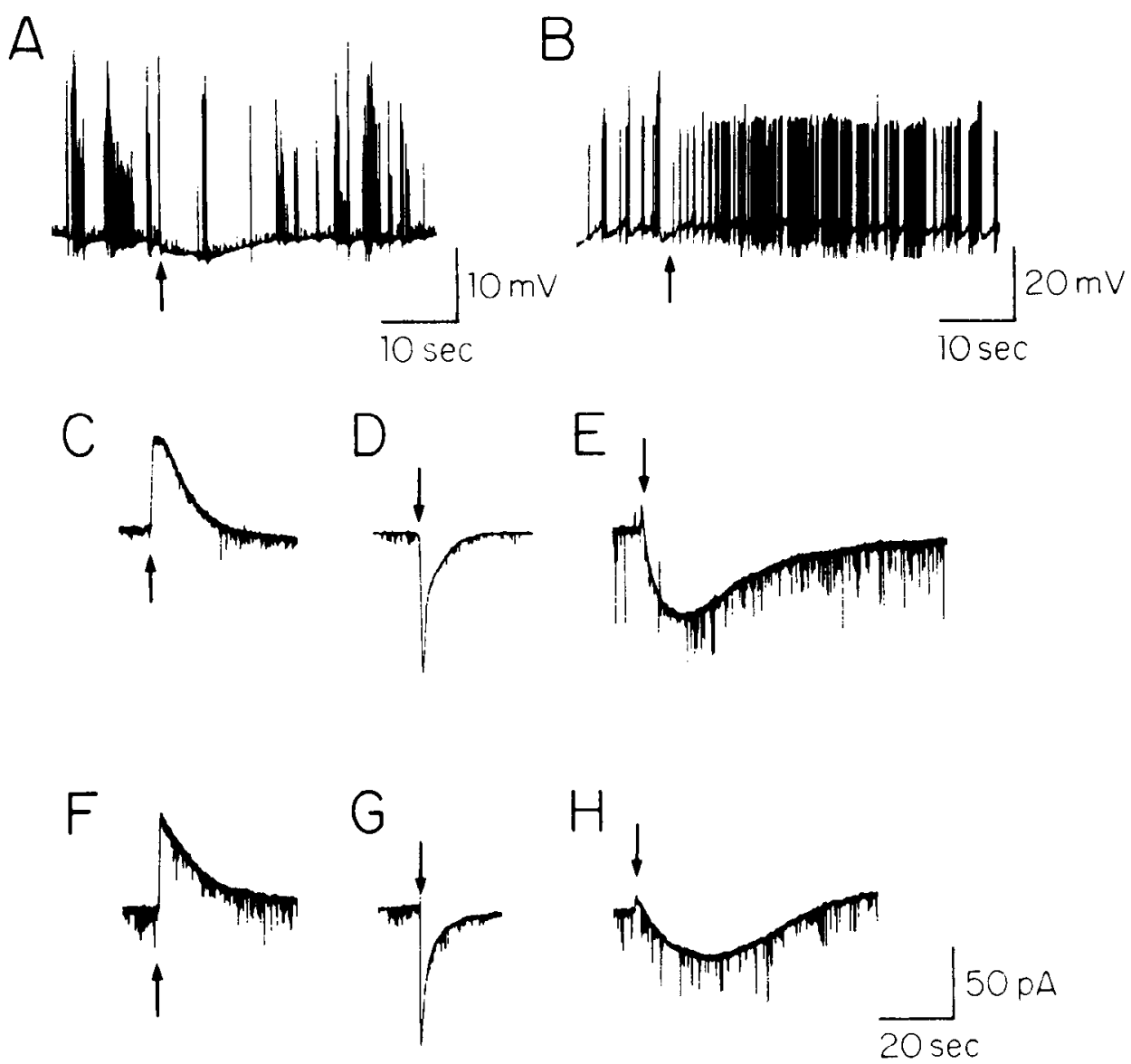

Figure 1. Chart records of responses of cultured neurons to $0.5 \mathrm{sec}$ pressure pulses of $10 \mu \mathrm{M} 5-\mathrm{HT}$, applied at the arrows. $A$ and $B$, Under current clamp, and in the absence of TTX, neurons exhibit spontaneous activity. Action potentials were attenuated by the time constant of the chart recorder. $A, 5-\mathrm{HT}$ hyperpolarized one hippocampal neuron and reduced its spontaneous activity. $B, 5$-HT slightly depolarized one striatal neuron and increased its spontaneous activity. 5-HT-activated currents are displayed from hippocampal neurons $(C-E)$ and striatal neurons $(F-$ $H$ ) voltage-clamped at $-70 \mathrm{mV}$ and in the presence of TTX to block action potentials. $C$ and $F$ show slow outward currents $\left(\mathrm{S}_{\text {out }}\right) ; D$ and $G$ show fast inward currents $\left(\mathrm{S}_{\text {f-in }}\right) ; E$ and $H$ show slow inward currents $\left(\mathrm{S}_{\mathrm{s}-\mathrm{in}}\right)$. not exclusively, from the pyramidal-shaped neurons. At present, we are unable to describe any correlation between cell morphology and 5-HT chemosensitivity.

Serotonin hydrochloride, 5 -methoxy- $N, N$-dimethyltryptamine oxalate (5-MeODMT), 8-hydroxy-2-(di-n-propylamino)-tetralin $\mathrm{HBr}$ (8OH-DPAT $), 1-(m$-chlorophenyl) piperazine $\mathrm{HCl}(\mathrm{CPP})$, and 1-(2-methoxyphenyl) piperazine $\mathrm{HCl}$ (MPP) were obtained from Research Biochemicals. Methysergide maleate was obtained from Sandoz. Forskolin was obtained from Calbiochem, and a $15 \mathrm{~mm}$ stock solution was prepared in ethanol. All other drugs were obtained from Sigma. All drugs except forskolin were dissolved in the bathing solution. The solution from which forskolin was applied was $0.4 \%$ ethanol in bathing solution. Forskolin-free control solutions were without effect. The $\mathrm{pH}$ of drug application solutions was readjusted to 7.2 when necessary. The concentrations of drugs used are mentioned in the text of the Results section and in the figurc lcgends. The drugs were usually delivered by pressure ejection from a picospritzer (General Valve Corp, Fairfield, NJ) with 5-10 psi pressure pulses ranging from $200 \mathrm{msec}$ to $1 \mathrm{sec}$ in duration (or as specified in Results) from aluminosilicate pipettes with tip diameters of approximately $0.5-1 \mu \mathrm{m}$. The drug pipettes were usually positioned $10-50 \mu \mathrm{m}$ away from the cell during application and moved away from the cell immediately after the pulse ended. The pressure application of control solutions rarely produced pressure artifacts. When pressure artifacts were seen, they had distinct features and bore no resemblance to any 5-HT responses. Occasionally, drugs were applied by perfusing the recording chamber with the particular drug dissolved in the appropriate bathing solution.

\section{Results}

\section{Three responses to $5-\mathrm{HT}$}

Cultured hippocampal and striatal neurons generate spontaneous bursts of action potentials (Fig. 1). Some spontaneously bursting neurons responded to 5-HT application with decreases
(Fig. 1A), while other neurons responded with increases in their bursting frequency (Fig. $1 B$ ). A substantial fraction of these neurons did not respond to 5-HT. The inhibitory responses to 5-HT were associated with slow transient hyperpolarizations, typically between 2 and $6 \mathrm{mV}$ (Fig. $1 A$ ). The excitatory responses were most often associated with longer-lasting depolarizations, typically between 2 and $4 \mathrm{mV}$ (Fig. $1 B$ ).

In order to explore the membrane conductance changes during these responses, action potentials were blocked with $0.5 \mu \mathrm{M}$ TTX and cells were voltage-clamped. Three distinct responses were elicited in both hippocampal neurons (Fig. 1, $C-E$ ) and striatal neurons (Fig. 1, $F-H$ ). The frequencies of occurrence of these responses are summarized in Table 1 . In all examples shown in Figure 1, the responses were evoked by $500 \mathrm{msec}$ pulses of 10 $\mu \mathrm{M}$ 5-HT. The most common response was an outward current that will be referred to as $S_{\text {out }}$ (Fig. 1, C, F). A fast inward current (Fig. 1, D, G) and a slow inward current (Fig. 1, $E, H$ ) were seen less often; they will be referred to as $S_{\text {f-in }}$ and $S_{\text {s-in }}$, respectively. There was clearly a higher incidence of $S_{s-i n}$ in cultured striatum than hippocampus. The differences in the frequencies of $S_{\text {out }}$ and $S_{f-\text { in }}$ between cultured striatum and hippocampus were not as striking and were difficult to evaluate. In 187 out of 196 of the 5-HT-sensitive cells only one response to 5-HT was generated; cells with 2 responses were rare.

In addition to the 5-HT responses, Figure $1, C-H$, shows frequent brief spontaneous inward currents, which appear to be synaptic in origin. These events were not blocked by TTX; their frequency increased with the age of the cultures, as was the 

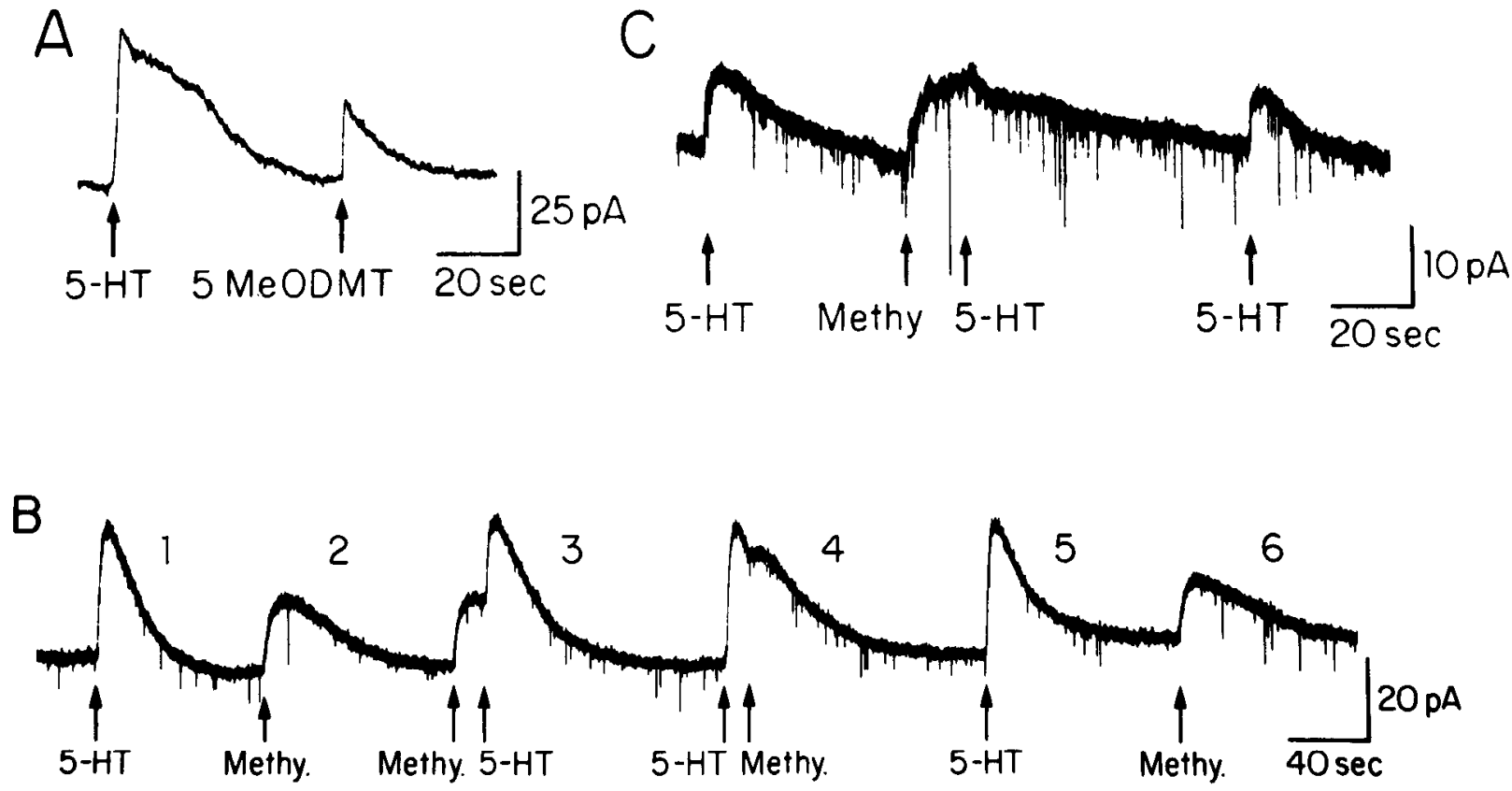

Figure 2. Pharmacology of $\mathrm{S}_{\text {out }}$. Neurons were voltage-clamped at $-70 \mathrm{mV}$. A, Responses first to 5-HT and then to 5-McODMT, both applied at $10 \mu \mathrm{M}$ in $0.5 \mathrm{sec}$ pressure pulses. $B$, Responses of a hippocampal neuron first to a 1 sec pulse of $50 \mu \mathrm{M} 5$-HT and then to a 1 sec pulse of 200 $\mu \mathrm{M}$ methysergide. The third and fourth events show methysergide and 5-HT applied in close succession. During the third event, 5-HT was applied while the methysergide response was at its peak. The fourth event shows responses to the same pair of drugs applied in the opposite sequence. The last 2 responses are repeats of the first 2 , in the same order. $C$, Responses of a striatal neuron first to a 1 sec pulse of $20 \mu \mathrm{M} 5$-HT and second to $200 \mu \mathrm{M}$ methysergide followed shortly by a pulse of $5-\mathrm{HT}$, while the methysergide response was near its peak. The third event is a repeat of the first.

fraction of cells in which excitatory synaptic events were seen with a loose patch recording (Jackson et al., 1988). Inhibitory postsynaptic currents were also observed, but much less frequently.

The large differences in the time courses of the 35 -HT responses made the time course an important distinguishing feature. $\mathrm{S}_{\text {out }}$ (Fig. 1, C, F) generally peaked 1-3 sec after the 5-HT pulse ended and typically required $10-25$ sec to decay completely (depending upon the length of the pressure pulse and the concentration of 5-HT used). This response was similar in many respects to the response of these cells to adenosine described by Trussell and Jackson (1985). In contrast, $\mathrm{S}_{\text {f-in }}$ (Fig. 1, $D, G$ ) had a more rapid onset and often peaked within $200 \mathrm{msec}$ after the beginning of a 5-HT pulse. $\mathrm{S}_{\mathrm{f}-\mathrm{in}}$ decayed within 2-4 sec when the holding potential was $-70 \mathrm{mV} . \mathrm{S}_{\text {s-in }}$ (Fig. 1, E, $H$ ) usually peaked 7-10 sec after the 5-HT pulse ended and required more than $30 \mathrm{sec}$ to decay completely.

Because of the infrequent occurrence of both $S_{\mathrm{f}-\text { in }}$ and $S_{\mathrm{s}-\mathrm{in}}$, our pharmacological characterization of these responses was less thorough than that of $S_{\text {out }}$. Nevertheless, pharmacological separation of all 3 of these responses was achieved.

Table 1. Frequency of observing different 5-HT responses in cultured hippocampus and striatum

\begin{tabular}{lllll} 
Tissue & $\mathrm{S}_{\text {out }}$ & $\mathrm{S}_{\mathrm{f}-\text { in }}$ & $\mathrm{S}_{\text {s-in }}$ & $N$ \\
\hline Striatum & 0.45 & 0.06 & 0.22 & 138 \\
Hippocampus & 0.35 & 0.10 & 0.07 & 200
\end{tabular}

Neurons were voltage-clamped at $-70 \mathrm{mV}$, and the response to a $500 \mathrm{msec}$ pulse of $10 \mu \mathrm{M} 5-\mathrm{HT}$ was recorded. The minimum resolvable current was $2 \mathrm{pA}$.
Slow inhibitory response, $\mathrm{S}_{\text {out }}$

\section{Pharmacology}

Table 2 summarizes the pharmacological results presented here. The indolealkylamine 5-MeODMT is an agonist of 5-HT receptors in the mammalian CNS (deMontigny and Aghajanian, 1977; Mosko and Jacobs, 1977; Sills et al., 1984). 5-MeODMT application produced a response similar in time course, current

Table 2. Pharmacological results

\begin{tabular}{|c|c|c|c|c|c|c|}
\hline \multirow[b]{2}{*}{ Agent } & \multicolumn{2}{|l|}{$\mathrm{S}_{\text {out }}$} & \multicolumn{2}{|l|}{$S_{\text {fin }}$} & \multicolumn{2}{|l|}{$\underline{S_{s-i n}}$} \\
\hline & $\begin{array}{l}\text { Hippo- } \\
\text { campus }\end{array}$ & $\begin{array}{l}\text { Stri- } \\
\text { atum }\end{array}$ & $\begin{array}{l}\text { Hippo- } \\
\text { campus }\end{array}$ & $\begin{array}{l}\text { Stri- } \\
\text { atum }\end{array}$ & $\begin{array}{l}\text { Hippo- } \\
\text { campus }\end{array}$ & $\begin{array}{l}\text { Stri- } \\
\text { atum }\end{array}$ \\
\hline \multicolumn{7}{|l|}{ Agonist action } \\
\hline 5-MeODMT & $4 / 4$ & $6 / 6$ & $0 / 2$ & $0 / 4$ & $0 / 4$ & $0 / 1$ \\
\hline 8-OH-DPAT & $0 / 3$ & $0 / 2$ & - & - & - & - \\
\hline $\mathrm{CPP}$ & $0 / 3$ & - & - & - & - & - \\
\hline MPP & $0 / 4$ & - & - & - & - & - \\
\hline Methysergide & $3 / 4$ & $2 / 4$ & $0 / 4$ & - & $0 / 3$ & $0 / 1$ \\
\hline \multicolumn{7}{|l|}{ Antagonist action } \\
\hline Metoclopramide & $0 / 3$ & $0 / 2$ & $4 / 4$ & - & - & - \\
\hline$d$-Tubocurarine & - & - & $3 / 3$ & - & - & - \\
\hline Methysergide & $0 / 4$ & $0 / 4$ & $0 / 4$ & - & $4 / 4$ & $1 / 1$ \\
\hline
\end{tabular}

Cells found to respond to 5-HT were then tested with the pharmacological agents as listed. The table gives results as the number of cells sensitive to a drug divided by the number of cells that produced the indicated 5-HT response. Methysergide was tested for both agonist and antagonist activity at $200 \mu \mathrm{M}$ for $\mathrm{S}_{\mathrm{out}}$ and $20 \mu \mathrm{M}$ for the other 2 responses. 5-MeODMT, 8-OH-DPAT, CPP, and MPP were tested at $10 \mu \mathrm{M}$ in all cases, while metoclopramide and $d$-tubocurarine were tested at 20 $\mu \mathrm{M}$. 

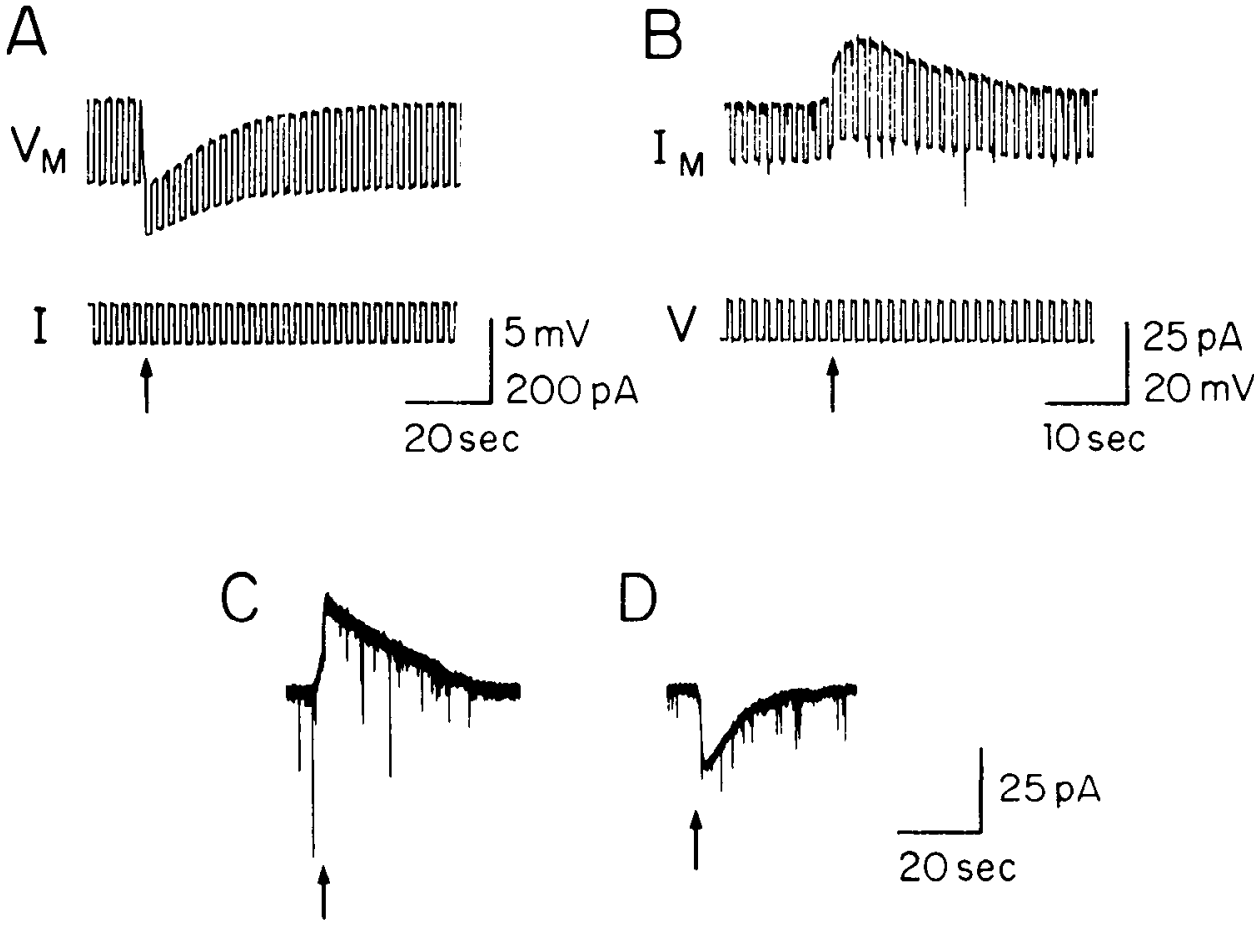

direction, and reversal potential to $S_{\text {out }}$ in hippocampal and striatal neurons (Fig. $2 A$ ). The amplitude of the 5-MeODMT response calculated as a fraction of the $5-\mathrm{HT}$ responsc in the same cell was $56 \pm 16 \%$ (mean $\pm \mathrm{SD}, n=4$ cells) for hippocampal and $56 \pm 19 \%(n=6$ cells) for striatal neurons. The 5 -MeODMT response was seen only in cells that responded to 5-HT with $S_{\text {out }}$ and was never larger than the 5-HT response. In addition, 5-MeODMT application resulted in an increased membrane conductance, similar to that observed for $\mathrm{S}_{\text {out }}$.

8-OH-DPAT has been reported to be a selective agonist of the $5-\mathrm{HT}_{1 \mathrm{a}}$ receptor (Peroutka, 1985) and to mimic the 5-HTactivated potassium conductance increase in rat hippocampal slices (Andrade et al., 1986). CPP has been reported to be a selective 5-HT ${ }_{1 \mathrm{~h}}$ agonist (Sills et al., 1984), and MPP has been reported to be a selective 5-HT, agonist (Lyon et al., 1986). None of these 5-HT agonists elicited $S_{\text {out }}$ in hippocampal neurons (Table 2). In addition, 8-OH-DPAT did not elicit $S_{\text {out }}$ in striatal neurons (Table 2).

Metoclopramidc has bcen reported to be a potent antagonist of 5-HT receptors of the terminal sympathetic neurons of the rabbit heart (Fozard and Ali, 1978). Metoclopramide (20 $\mu \mathrm{M})$ produced no significant reduction in the amplitude of $S_{\text {out }}$ in either hippocampal or striatal neurons (Table 2). However, high doses of metoclopramide $(200 \mu \mathrm{M})$ were observed to reduce the amplitude of $\mathrm{S}_{\text {out }}$ in hippocampal neurons by $49 \pm 22 \%(n=8$ cells) but not in striatal neurons ( $n-4$ cells).

Methysergide has been reported to block 5-HT responses (Leysen, 1985), including a 5-HT-induced potassium conductance increase in rat hippocampal slices (Segal, 1980). However, $200 \mu \mathrm{M}$ methysergide failed to reduce $\mathrm{S}_{\text {out }}$ elicited by $5-\mathrm{HT}$ in hippocampal and striatal neurons. Figure $2 B$ shows a voltageclamp recording from a hippocampal neuron in which methysergide not only did not block $S_{\text {out }}$ but produced a response identical in time course and direction to $\mathrm{S}_{\text {out }}$. In addition, when
Figure 3. Conductance changes associated with $\mathrm{S}_{\text {ou. }} . A$, A current-clamped hippocampal neuron was hyperpolarized by a 1 sec pulse of $10 \mu \mathrm{M} 5-\mathrm{HT}$ and the responses to $100 \mathrm{pA}$ test current pulses became smaller. $B$, A voltageclamped hippocampal neuron responded to a 1 sec pulse of $10 \mu \mathrm{M}$ 5-HT with an outward current and current responses to $10 \mathrm{mV}$ test pulses became larger. $C$, Replacing $\mathrm{K}$-gluconate of the patch electrode filling solution with $\mathrm{KCl}$ (see Materials and Methods) changes the chloride driving force by moving the Nernst potential to $0 \mathrm{mV}$. 5 -HT still elicited an outward current identical to $\mathrm{S}_{\text {out }}$, when the striatal cell was voltageclamped at $-70 \mathrm{mV}$. $D$, When the Nernst potential for potassium was shifted to $-65 \mathrm{mV}$ by increasing the potassium concentration of the bathing solution to $10 \mathrm{~mm}$ (see Materials and Methods), 5-HT elicited an inward current from a hippocampal cell voltageclamped at $-70 \mathrm{mV}$. The response was identical to $S_{\text {out }}$ in time course.
5-H I and methysergide were administered simultaneously, the combined current response was not additive, i.e., the combined responsc was less than the sum of the individual responses to 5-HT and methysergide alone (Fig. $2 B$ ). The same result was obtained in striatal neurons (Fig. 2C). Concentrations of methysergide as high as $200 \mu \mathrm{M}$ still left the response equal to or smaller than the responses to 5-HT [50 $\mu \mathrm{M}$ for a hippocampal cell (Fig. $2 B$ ) and $20 \mu \mathrm{M}$ for a striatal cell (Fig. 2C)]. These data suggest that methysergide can weakly activate the $S_{\text {out }}$ receptor (see Discussion).

Because $S_{\text {out }}$ is so similar to an adenosine-activated potassium conductance studied in this laboratory (Trussell and Jackson, 1985), we tested the effect of the adenosine receptor blocker theophylline on $S_{\text {out }}$. A brief pulse of $1 \mathrm{~mm}$ theophylline completely blocked the adenosine response in cultured striatum (Trussell and Jackson, 1985). Bath application of $0.5 \mathrm{~mm}$ theophylline had no effect on $S_{\text {out }}$ elicited by $5-\mathrm{HT}$ in either hippocampal ( 4 of 4 cells) or striatal ( 2 of 2 cells) neurons. This indicates that adenosine and 5-HT act at different receptors in producing a similar potassium conductance increase.

\section{Physiology}

Current- and voltage-clamp recordings of $\mathrm{S}_{\mathrm{out}}$ are shown in Figure $3, A$, and $B$, respectively, with appropriate current or voltage pulses to ascertain the membrane conductance changes during the response. There was a substantial increase in the membrane conductance; the average change was $38 \pm 16 \%(n=14$ cells $)$ for hippocampal neurons and $34 \pm 19 \%(n=13$ cells $)$ for striatal neurons. The conductance changes were measured when the membrane potential was $-70 \mathrm{mV}$.

In order to test the involvement of a chloride conductance increase during $S_{\text {out }}$, we replaced the potassium gluconate of the electrode filling solution with potassium chloride (as described in Materials and Methods). This shifted the chloride Nernst 


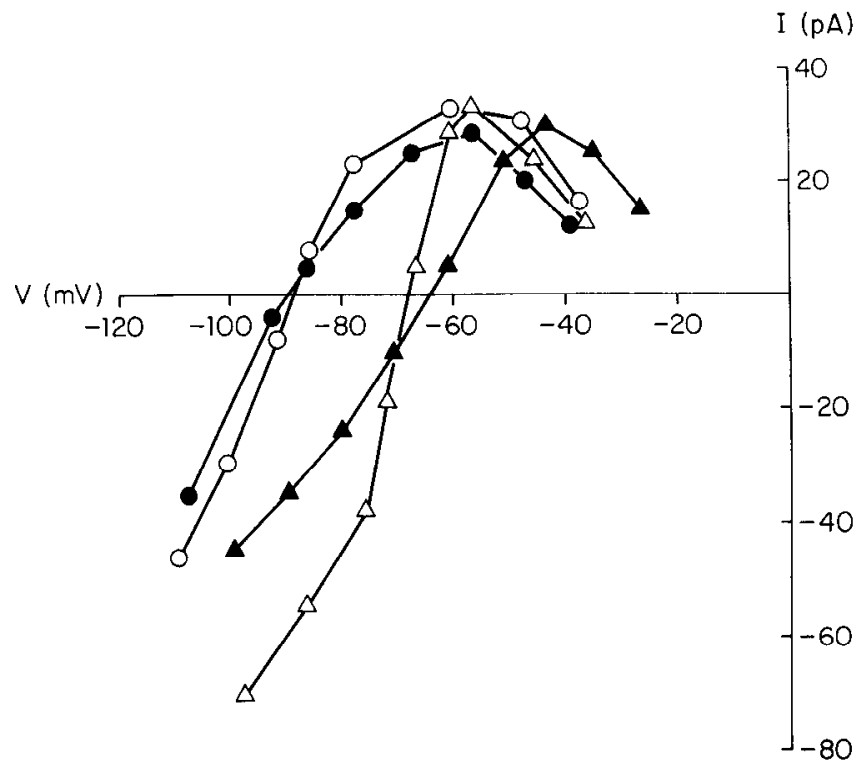

Figure 4. Current-voltage relations of $\mathrm{S}_{\text {out }}$ in hippocampal (filled symbols) and striatal (open symbols) neurons in bathing solutions of $4 \mathrm{~mm}$ (circles) and $10 \mathrm{~mm}$ (triangles) potassium. The peak current elicited by a $1 \mathrm{sec}$ pulse of $10 \mu \mathrm{M} 5-\mathrm{HT}$ is plotted versus the holding potential.

potential to $0 \mathrm{mV}$, without altering the Nernst potentials of the other ions. Figure $3 C$ shows a voltage-clamp recording of a cell filled with potassium chloride. $S_{\text {out }}$ remained outward, suggesting that $S_{\text {out }}$ was not due to an increased chloride conductance.

To test for an increase in a potassium conductance during $\mathrm{S}_{\text {out }}$, the value of the potassium ion reversal potential was shiftcd from $-90 \mathrm{mV}$ (for an intracellular potassium concentration of $145 \mathrm{~mm}$ and an extracellular concentration of $4 \mathrm{~mm}$ ) to -67 $\mathrm{mV}$ by elevating the bath potassium concentration to $10 \mathrm{~mm}$ (see Materials and Methods). Under these conditions, with a holding potential of $-70 \mathrm{mV}$, the driving force for potassium was inward. Figure $3 D$ shows that, when a hippocampal neuron was bathing in $10 \mathrm{~mm}$ potassium, an inward current, with the same time course as $S_{\text {out }}$, was generated by 5 -HT application. This result suggests that $S_{\text {ou }}$ was generated by an increased potassium conductance.

Current-voltage curves for $S_{\text {out }}$ in bathing solutions with 2 different potassium concentrations $(4$ and $10 \mathrm{~mm}$ ) provide further evidence for a potassium conductance increase during $S_{\text {out }}$ (Fig. 4). When the extracellular potassium was $4 \mathrm{~mm}$, the potassium Nernst potential was $-90 \mathrm{mV}$. $\mathrm{S}_{\text {out }}$ reversed at this potential in both hippocampal and striatal neurons (Fig. 4). Increasing the bathing potassium to $10 \mathrm{~mm}$ shifted the potassium Nernst potential to $-67 \mathrm{mV}$ and shifted the reversal potential of $S_{\text {out }}$ to $-65 \mathrm{mV}$ in a hippocampal neuron and -68 $\mathrm{mV}$ in a striatal neuron (Fig. 4). Figure 5 displays all of our data for the dependence of the reversal potential of $S_{\text {out }}$ on the concentration gradient of potassium ions. The reversal potentials of the responses of individual hippocampal (crosses) and striatal (circles) neurons bathing in solutions with 3 different external potassium ion concentrations $(3,4$, and $10 \mathrm{~mm})$ are plotted against the logarithm of the ratio of the external to internal potassium ion concentrations (the internal potassium ion concentration was $145 \mathrm{~mm}$ in all 3 cases). The close agreement between the reversal potentials of $S_{\text {out }}$ and the calculated Nernst potential for potassium (solid line) indicate that $S_{\text {out }}$ resulted from the activation of a potassium conductance.

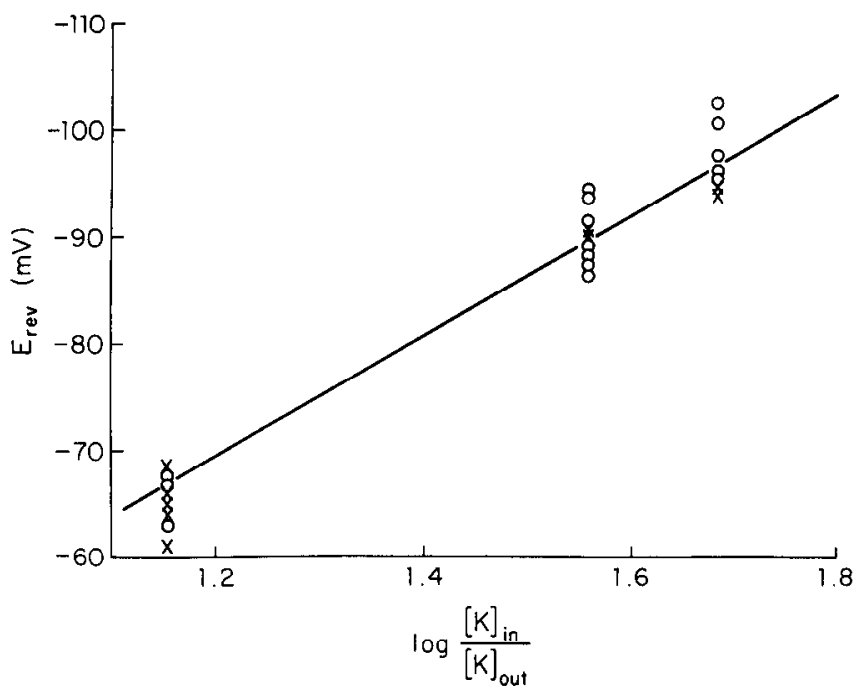

Figure 5. Reversal potentials of $\mathrm{S}_{\text {out }}$ are plotted versus the logarithm of the ratio of internal and external potassium concentrations. Data from individual hippocampal $(x)$ and striatal $(O)$ neurons are plotted. The internal potassium was $145 \mathrm{~mm}$ in all experiments, and the external potassium was 3,4 , and $10 \mathrm{~mm}$. The solid line was computed from the Nernst equation.

The current-voltage curves of Figure 4 indicate that $S_{\text {out }}$ was voltage dependent. As shown by the 4 different traces, the current-voltage curves were roughly linear near the reversal potentials and at hyperpolarized potentials. However, the slope conductance decreased and actually became negative at more depolarized potentials. This inward rectification was observed in all cells tested ( $n=23$ cells). This rectification is not likely to be due to an artifact of the recording system since the slope of the current-voltage curve for $\mathbf{S}_{\text {f-in }}$ did not change dramatically through the same voltage range in which the rectification of $S_{\text {out }}$ was observed (discussed below). In addition, the current-voltage curves for the responses of striatal neurons to norepinephrine (J. L. Yakel and M. B. Jackson, unpublished observations) and GABA (Trussell and Jackson, 1985) were also linear through the same voltage range.

It is of interest to know whether $S_{\text {out }}$ is dependent upon calcium ion influx. Both cadmium and cobalt block calcium channels in mammalian central neurons (Adams and Galvan, 1986). Neither $1 \mathrm{~mm}$ cadmium nor $1 \mathrm{~mm}$ cobalt applied from a large tipped pipette reduced the amplitude of $S_{\text {out }}$ in hippocampal and striatal neurons. This observation is in accord with the work of Segal (1980) and Jahnsen (1980), who found that blocking calcium influx had no effect on a 5-HT-activated potassium conductance in hippocampal neurons. The adenosine response in striatal neurons, which is similar to $S_{\text {out }}$, was also unaffected by $1 \mathrm{mM}$ cobalt (Trussell and Jackson, 1985).

Fast, excitatory response, $\mathrm{S}_{\mathrm{f} \text {-in }}$

Pharmacology

Table 2 indicates that 5-MeODMT was not an agonist of $\mathbf{S}_{\text {fin }}$ in hippocampal and striatal cultures. Methysergide had no action on hippocampal neurons that respond to 5-HT with $S_{\mathrm{r}-\mathrm{in}}$. Metoclopramide $(20 \mu \mathrm{M})$ was found to completely block $\mathbf{S}_{\text {fin }}$ in hippocampal neurons ( $n=4$ cells), and this effect was reversible (Fig. 6A). $d$-Tubocurarine has been shown to block excitatory 5-HT responses in rabbit nodose ganglia (Higashi and Nishi, 1982) and Aplysia neurons (Gerschenfeld and Paupardin-Tritsch, 

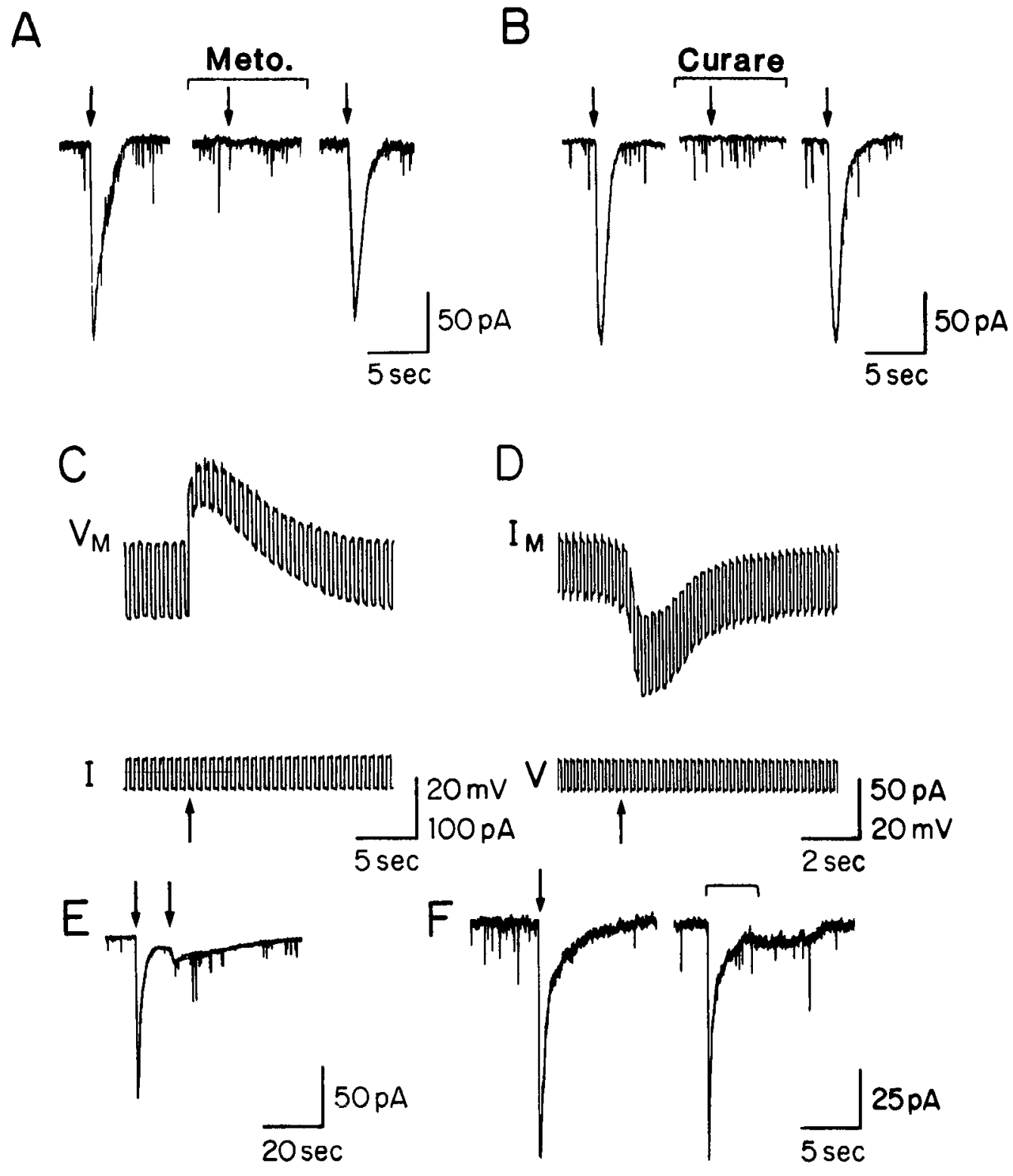

Figure 6. Characterization of $\mathrm{S}_{\mathrm{fin}}$. $A$. Response of a hippocampal neuron to a $0.5 \mathrm{sec}$ pulse of $10 \mu \mathrm{M} 5-\mathrm{HT}$. The bath application of $20 \mu \mathrm{M}$ metoclopramide (Meto.) completely blocked $\mathrm{S}_{\mathrm{f} \text {-in }}$. When metoclopramide was washed out, the response recovered completely. B, Response of a hippocampal neuron to a $0.5 \mathrm{sec}$ pulse of $20 \mu \mathrm{M} 5$-HT. The bath application of $20 \mu \mathrm{M} d$-tubocurarine (curare) completely blocked $\mathrm{S}_{\text {f-in. }}$. When $d$-tubocurarine was washed out, the response recovered completely. $C$, A current-clamped hippocampal neuron was depolarized by a 0.5 sec pulse of $10 \mu \mathrm{M} 5-\mathrm{HT}$ and the responses to $50 \mathrm{pA}$ test current pulses became smaller. $D$, A voltage-clamped hippocampal neuron responded to a 0.5 sec pulse of $50 \mu \mathrm{M} 5-\mathrm{HT}$ with an inward current and current responses to $10 \mathrm{mV}$ test pulses became larger. $E$, When 2 identical 0.5 sec pulses, separated by a $12 \mathrm{sec}$ interval, of $10 \mu \mathrm{M} 5-\mathrm{HT}$ were applied to a voltage-clamped striatal neuron, the sccond response was $90 \%$ smaller than the first. $F$, Responses of a voltage-clamped hippocampal neuron to $0.2 \mathrm{sec}$ and $4 \mathrm{sec}$ pulses of $20 \mu \mathrm{M} 5$-HT. The response desensitized during the longer pulse, unmasking a weak slow inward current $\left(S_{\text {s-in }}\right)$. All recordings displayed here were made from cells held at $-70 \mathrm{mV}$ except for $D$, in which the cell was held at $-80 \mathrm{mV}$.

1974). $d$-Tubocurarine $(20 \mu \mathrm{M})$ was found to completely and reversibly block $S_{f-i n}$ in hippocampal neurons ( $n=3$ cells; Fig. $6 B)$.

\section{Physiology}

Current- and voltage-clamp recordings of $S_{\text {f-in }}$ in hippocampal neurons are shown in Figure $6, C$ and $D$, respectively, with current or voltage pulses to ascertain the membrane conductance changes during this response. It is clear that there was a large increase in the membrane conductance during $S_{\text {fin }}$; the average change was $46 \pm 12 \%$ (mean $\pm \mathrm{SD}, n=6$ cells) for hippocampal and $43 \pm 9 \%$ (mean $\pm \mathrm{SD}, n=7$ cells) for striatal neurons.

$\mathrm{S}_{\mathrm{f} \text {-in }}$ exhibited strong desensitization. Figure $6 E$ shows a voltage-clamp recording of a striatal neuron that responded to 5-HT with $\mathrm{S}_{\mathrm{f} \text {-in }}$. The peak response was $135 \mathrm{pA}$ at a holding potential of $-70 \mathrm{mV}$. A second identical pulse approximately $12 \mathrm{sec}$ after the first elicited a response of only $10 \mathrm{pA}$. Figure $6 F$ shows 2 recordings of $\mathrm{S}_{\mathrm{f}-\mathrm{in}}$ from a hippocampal neuron elicited by a 200 msec and a $4 \mathrm{sec}$ pulse of $20 \mu \mathrm{M}$ 5-HT. Both pulses of 5-HT elicited a response of $100 \mathrm{pA}$. The response to the $200 \mathrm{msec}$ pulse of 5-HT (Fig. $6 F$ ) required about $4 \mathrm{sec}$ to decay back to 

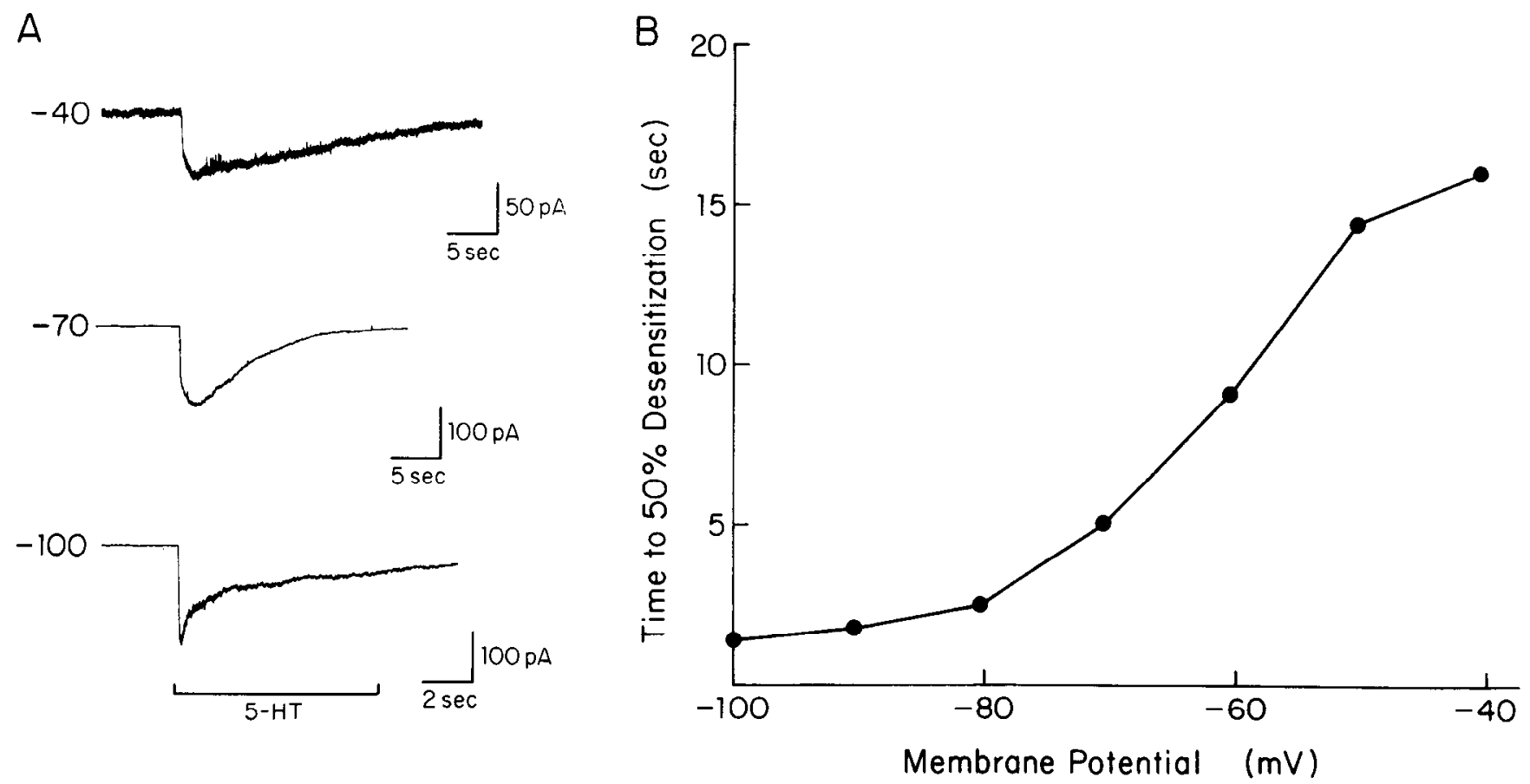

Figure 7. Densitization of $\mathrm{S}_{\mathrm{f}-\mathrm{in}}$ at different voltages. $A, 5$-HT activated fast inward currents at 3 different holding potentials, as indicated. 5-HT, $20 \mu \mathrm{M}$, was applied continuously to induce desensitization (as in Fig. $6 \mathrm{D}$ ). The time for a response to decay to $50 \%$ of its peak is plotted versus holding potential in $B$. Three to five minutes were allowed between each response to allow full recovery from desensitization. These recordings were made at $25^{\circ} \mathrm{C}$.

the original baseline current level after the 5-HT pulse ended. The response to the $4 \mathrm{sec}$ pulse of 5 -HT immediately began to decay after the maximum response was reached and had completely decayed before the pulse had ended (Fig. $6 F$ ). In this particular experiment, a weak slow inward current appeared after the desensitization of $S_{\text {fin }}$ and was probably due to the activation of a weak $S_{\text {sin }}$ response that was not observed during the brief $200 \mathrm{msec}$ pulse of 5-HT. Thus, this was a rare instance of a cell that exhibited 2 responses.

The time course of desensitization was found to be voltagedependent. Figure $7 A$ shows responses to desensitizing pulses of 5 -HT at 3 different membrane potentials. It is clear from these recordings that the rate of desensitization varied with voltage. Figure $7 B$ plots the time required for $S_{\mathrm{f} \text { in }}$ to decay to $50 \%$ of its peak $\left(t_{1_{2}}\right)$ during continuous application $(5-30 \mathrm{sec})$ of $20 \mu \mathrm{M} 5$-HT at a variety of membrane holding potentials. The value of $t_{1 /}$ ranged from $1.6 \mathrm{sec}$ at a holding potential of -100 $\mathrm{mV}$ to $16 \mathrm{sec}$ at a holding potential of $-40 \mathrm{mV}$. At more negative holding potentials, the decay of the response to a prolonged application of 5-HT showed 2 components (Fig. $7 A,-100 \mathrm{mV}$ ), suggesting that desensitization of this response was biphasic. Thus, $t_{1 / 2}$ did not reflect a single rate process.

The current-voltage curve for $S_{\text {f-in }}$ was determined in both striatal and hippocampal neurons (Fig. 8). The reversal potential was $-15 \mathrm{mV}$ in a striatal neuron bathing in $3 \mathrm{mM} \mathrm{KCl}$ and -7 $\mathrm{mV}$ in a hippocampal neuron bathing in $10 \mathrm{~mm} \mathrm{KCl}$. Similar current-voltage curves and reversal potentials were obtained for this response from other neurons. The reversal potential was similar to the reversal potential of $+7 \mathrm{mV}$ in rabbit nodose ganglion (Higashi and Nishi, 1982) and of $-10 \mathrm{mV}$ in a neuroblastoma $\times$ glioma hybrid cell line (NG108-15) (Christian et al., 1978) obtained for similar rapid depolarizing 5-HT re- sponses. Based on the reversal potential, it is likely that $S_{f-i n}$ was due to an increase in the membrane permeability to both sodium and potassium ions. The time course, reversal potential, and desensitization of the response described by Christian et al. (1978) were very similar to those of $S_{\text {f-in }}$ described here. The current-voltage curves of Figure 8 also indicate that the slope conductance of $\mathbf{S}_{\text {f-in }}$ decreased at depolarized potentials.

Slow excitatory response, $\mathrm{S}_{\mathrm{s}-\mathrm{n}}$

Pharmacology

5-MeODMT did not elicit $S_{\text {sin }}$ in hippocampal and striatal neurons that were already found to respond to $5-\mathrm{HT}$ with $\mathrm{S}_{\text {s-in }}$ (Table 2). Methysergide ( $20 \mu \mathrm{M}$ ) was found to block $\mathrm{S}_{\mathrm{s}-\mathrm{in}}$ in hippocampal and striatal neurons (Fig. 9, $A$ and $B$ ). A hippocampal neuron that responded with $\mathrm{S}_{\mathrm{s}-\mathrm{in}}$ to a $200 \mathrm{msec}$ pulse of $10 \mu \mathrm{M} 5-\mathrm{HT}$ is shown in Figure $9 A$. The increase in noise occasionally seen with this response may be due to increased synaptic activity or increased channel activity. When 5-HT application was immediately preceded by a $200 \mathrm{msec}$ pulse of $20 \mu \mathrm{M}$ methysergide, $\mathrm{S}_{\mathrm{s} \text {-in }}$ was completely blocked (Fig. $9 A$ ). Fifty percent recovery of this response is shown $3 \mathrm{~min}$ after the removal of methysergide (Fig. 9A). Figure $9 B$ shows another rare hippocampal neuron that displayed both $S_{\text {fin }}$ and $S_{\text {s.in }}$ in response to a $200 \mathrm{msec}$ pressure pulse of $10 \mu \mathrm{M}$ 5-HT (Fig. 9B). When the same application of 5-HT was immediately preceded by a $500 \mathrm{msec}$ pulse of $20 \mu \mathrm{M}$ methysergide, $S_{\mathrm{f}-\mathrm{in}}$ was unaffected, but $\mathrm{S}_{\mathrm{s} \text {-in }}$ was completely blocked (Fig. $9 B$ ).

\section{Physiology}

A voltage-clamp recording of $S_{\text {sin }}$ in a striatal neuron is shown in Figure $9 C$, with voltage pulses to ascertain the membrane conductance changes during the response. We always observed 


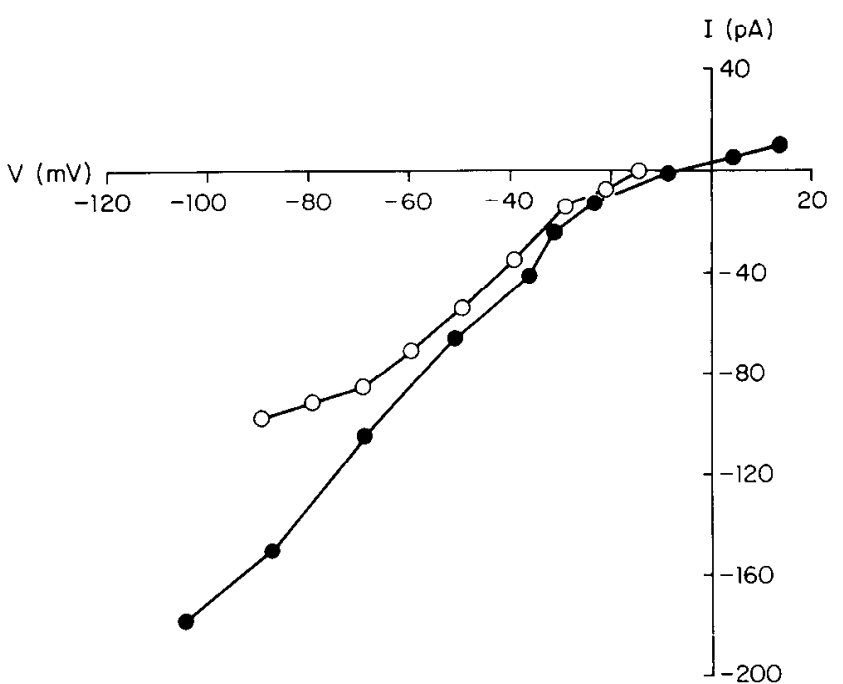

Figure 8. Current-voltage relations of $\mathrm{S}_{\mathrm{f}-\mathrm{in}}$ in a hippocampal neuron bathing in $10 \mathrm{~mm}$ potassium (filled circles) and a striatal neuron bathing in $3 \mathrm{~mm}$ potassium (open circles).

a small increase in membrane conductance during $\mathrm{S}_{\text {s-in }}$; the average change was $10 \pm 1 \%$ (mean $\pm \mathrm{SD}, n=5$ cells) in striatal neurons and $10 \%(n=1)$ in a hippocampal neuron.

Due to the low frequency with which this response was observed, and the fact that the response usually decreased with time during a recording, even when high-resistance electrodes were used (discussed below), only a partial current-voltage curve (from -50 to $-90 \mathrm{mV}$ ) was obtained (Fig. 10A). The decrease in the magnitude of this response as the membrane was depolarized was consistent with an underlying conductance increase.

$\mathrm{S}_{\mathrm{s} \text {-in }}$ was similar in many respects (e.g., current direction, conductance change, time coursc) to responses to norepinephrine (Fig. 10B), the adenylate cyclase activator forskolin (Fig. 10C), and dopamine (data not shown). Receptor-dependent stimulation of adenylate cyclase by 5-HT, norepinephrine, and dopamine has been reported in mammalian brain (Nestler and Greengard, 1984) and cultured striatum (Premont et al., 1983). Forskolin activates adenylate cyclase by a direct interaction with the enzyme (Seamon et al., 1981).

\section{Loss of $5-\mathrm{HT}$ responses}

Whole-cell recordings such as those carricd out herc allow the patch-electrode filling solution to exchange with the contents of the cell (Hamill et al., 1981; Marty and Neher, 1983). Membrane properties that are influenced by the cytoplasm can thus be profoundly affected. During whole-cell recordings the input resistance of the cells decreased an average of $40 \pm 19 \%(n=5$ cells; membrane potential, $-70 \mathrm{mV}) 5 \mathrm{~min}$ after the cells were penetrated in low series resistance recordings. This input resistance change was accompanied by a slowly developing outward current that required from 1.5 to greater than $15 \mathrm{~min}$ to reach a plateau. The resting membrane potential usually became more negative during the recordings, probably as a result of this outward current.

$\mathrm{S}_{\text {out }}$ was found to decrease with time when a low series resistance electrode was used to record the response from either hippocampal or striatal neurons (Fig. 11). However, when a high scries resistance electrode was used, the dialysis of the cell was much slower, and the response did not decrease with time. The decay of a membrane current following the internal dialysis of a cell is often referred to as "washout." It is well known that calcium currents wash out in perfused snail neurons (Byerly and Hagiwara, 1982). The adenosine-activated potassium current in cultured striatal neurons also washed out (Trussell and Jackson, 1985).

Figure 11 shows the time course of washout for $\mathrm{S}_{\text {out }}$ during a low series resistance recording from a striatal (filled circles) and a hippocampal (open circles) neuron in which the series resistances were 17 and $15 \mathrm{M} \Omega$, respectively. The responses are plotted as a percentage of the first response obtained immediately after the intracellular recording was established. $S_{\text {ou }}$ had completely disappeared by $7.5 \mathrm{~min}$ in both cells. The time course of washout of $\mathrm{S}_{\text {out }}$ was approximately similar to the time course of change in cell input resistance and the appearance of the outward current described above.

In recordings obtained with high series resistance electrodes (between 100 and $125 \mathrm{M} \Omega$ ) from a striatal (filled squares) and a hippocampal neuron (open squares), $S_{\text {out }}$ did not decline, even after $15 \mathrm{~min}$. When the responsiveness of striatal cells to the transmitter GABA was tested with low series resistance electrodes, this responsc did not wash out (Trussell and Jackson,
A
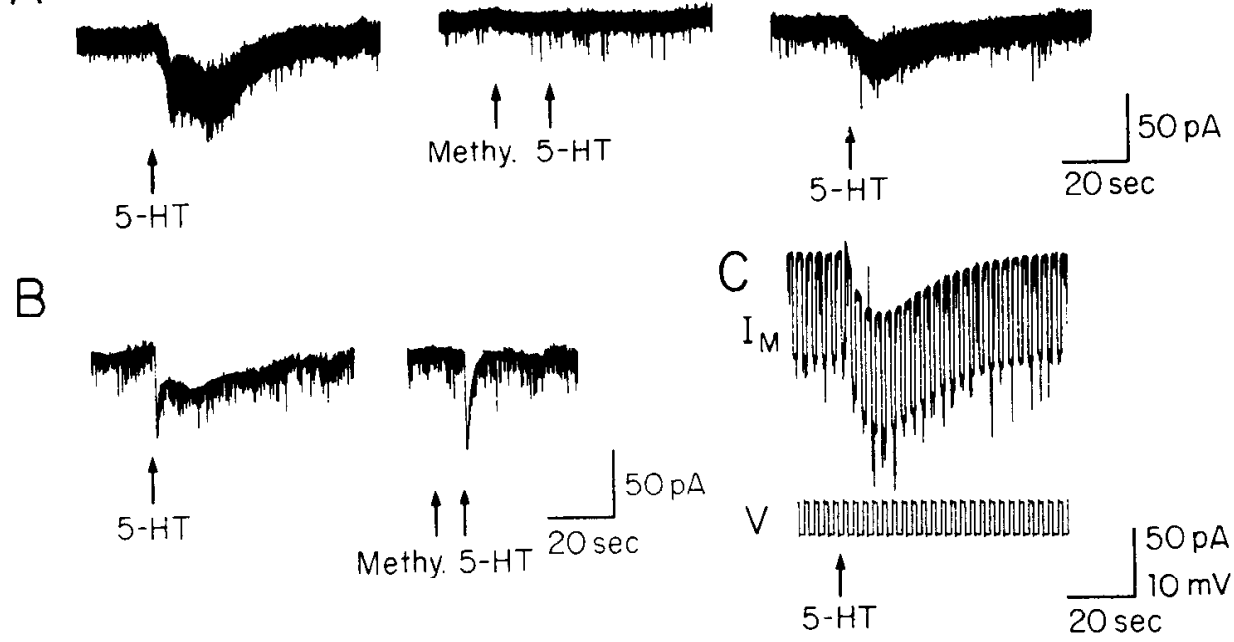

Figure 9. Characterization of $\mathrm{S}_{\mathrm{s}-\mathrm{in}} \cdot A$, Response of a hippocampal neuron to a $0.2 \mathrm{sec}$ pulse of $10 \mu \mathrm{M} 5$-HT. A 0.2 sec pulse of $20 \mu \mathrm{M}$ methysergide, applied immediately before the 5-HT was applied, blocked $S_{\text {sin }}$. Three minutes later, $S_{s}$ in recovered to $50 \%$ of its original magnitude. $B, \mathrm{~A} 0.2 \mathrm{sec}$ pulse of $10 \mu \mathrm{M} 5$-HT elicited both $\mathrm{S}_{\mathrm{f}-\mathrm{in}}$ and $\mathrm{S}_{\mathrm{s}-\mathrm{in}}$. These 2 responses were easily distinguished on the basis of their time courses. A $0.5 \mathrm{sec}$ pulse of $20 \mu \mathrm{M}$ methysergide applied immediately before 5 -HT blocked $S_{\text {sin }}$ and left $S_{\text {f-in }}$ unaffected. $C$, A voltage-clamp recording of $S_{\text {s-in }}$ with test pulses showed that $S_{\text {s-in }}$ was accompanied by a conductance increase. All responses displayed in this figure were recorded from cells held at $-70 \mathrm{mV}$. 


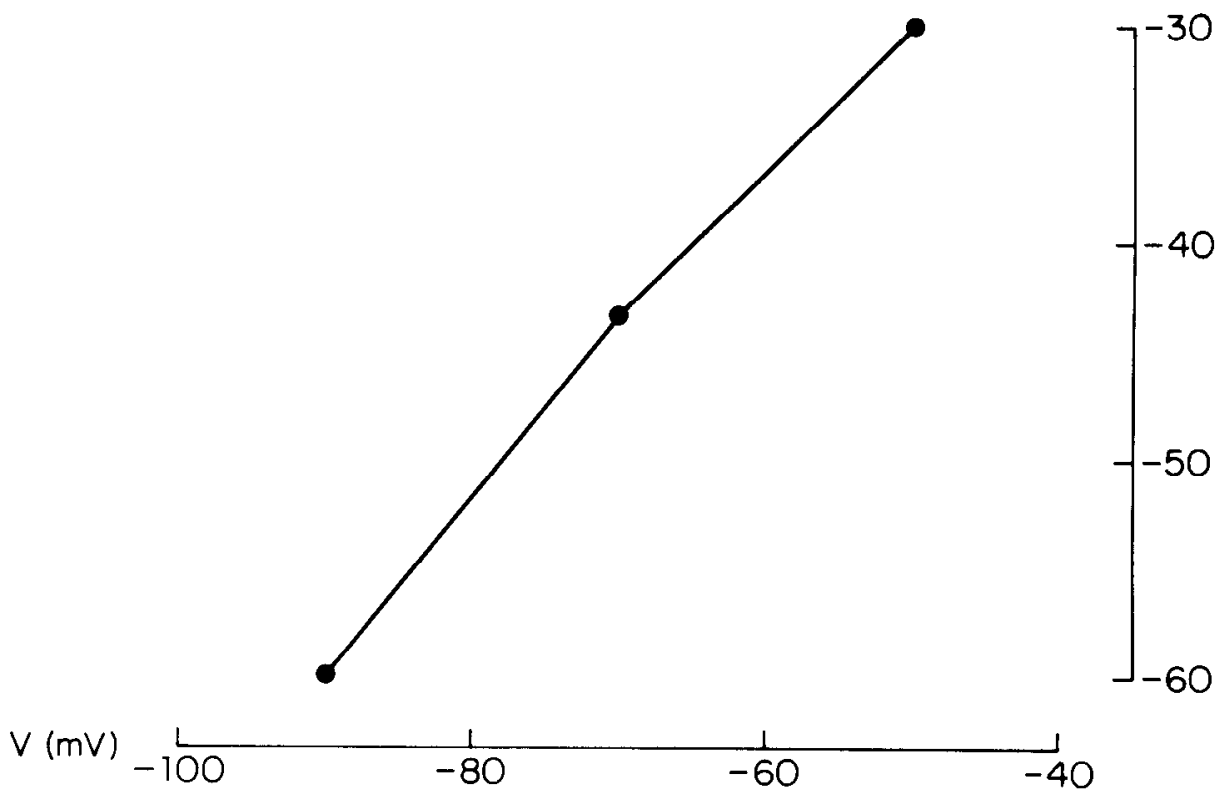

Figure 10. A, A current-voltage relation of $S_{\text {s-in }}$ in a striatal neuron bathing in $4 \mathrm{~mm}$ potassium. $B$, A slow inward current elicited by a 1 sec pulse of 10 $\mu \mathrm{M}$ norepinephrine. $C$, A slow inward current elicited by a 1 sec pulse of 60 $\mu \mathrm{M}$ forskolin. In $B$ and $C$, cells were held at $-70 \mathrm{mV}$

B

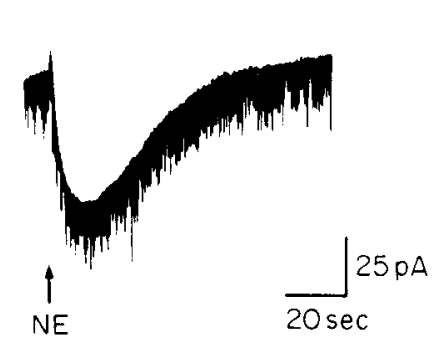

C

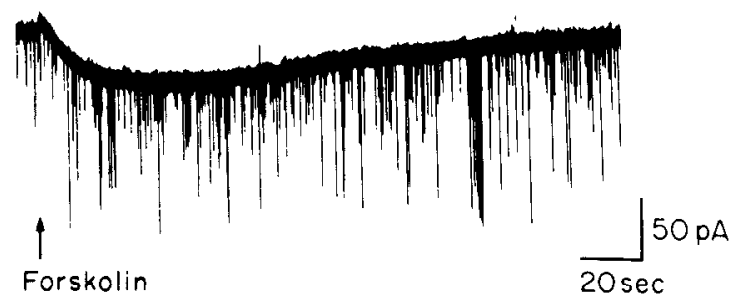

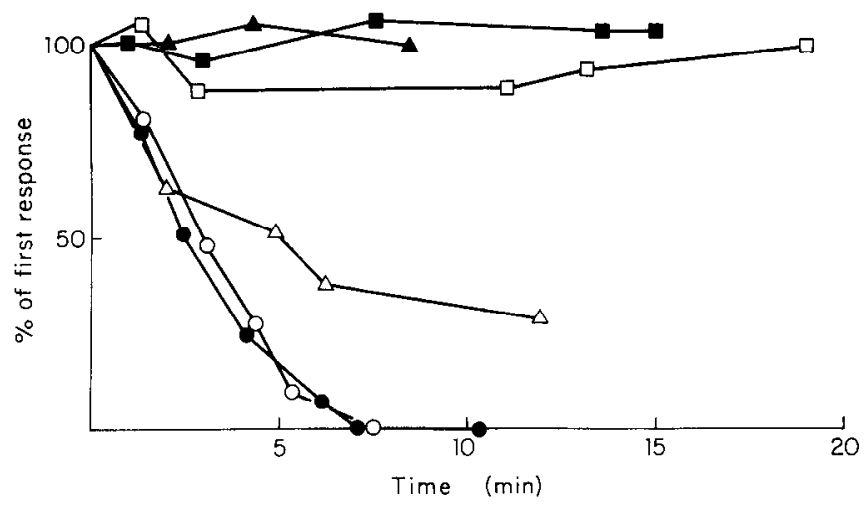

Figure 11. Variations in 5-HT responses with time after initiation of an intracellular recording. All responses were recorded from cells voltage-clamped at $-70 \mathrm{mV}$. The first response was recorded a few seconds after rupture of the membrane patch, and is plotted at $t=0$. Subsequent responses were normalized to the first response. $\bullet, S_{\text {out }}$ recorded from a striatal neuron with a $17 \mathrm{M} \Omega$ series resistance; $O, S_{\text {out }}$ recorded from a hippocampal neuron with a $15 \mathrm{M} \Omega$ series resistance;,$S_{\text {out }}$ recorded from a striatal neuron with a $100 \mathrm{M} \Omega$ series resistance; $\square, S_{\text {out }}$ recorded from a hippocampal neuron with a $125 \mathrm{M} \Omega$ series resistance; $\Delta, \mathrm{S}_{\mathrm{f}-\mathrm{in}}$ recorded from a striatal neuron with a $15 \mathrm{M} \Omega$ series resistance; $\Delta, S_{\text {s-in }}$ recorded from a hippocampal neuron with a $100 \mathrm{M} \Omega$ series resistance.
1985). In addition, glutamate responses did not wash out with low series resistance recordings in these neurons (D. Finch, L. Trussell, and M. Jackson, unpublished observations). The superficial appearance of the cells did not change as washout progressed.

The decline in $\mathrm{S}_{\text {out }}$ seen with low series resistance recordings is not likely to represent desensitization for the following reasons. Tests with pulses of 5-HT as long as 1 min showed no desensitization. The decline in sensitivity was not seen in recordings with high series resistance. The decline occurs even when 5-HT was applied infrequently, when there were prolonged periods without application.

Figure 11 shows $S_{\text {fin }}$ in a low series resistance recording (filled triangles) and $S_{\text {s-in }}$ in a high series resistance recording (open triangles) plotted versus time after initiation of the intracellular recording. There was no decrease in the amplitude of $S_{\text {f-in }}$ in 8 min, sufficiently long to allow complete washout of $S_{\text {out }}$ during a low series resistance recording. In general, $S_{f-i n}$ lasted as long as the recording, without any diminution. On some occasions recordings of a cell exhibiting $S_{f-i n}$ lasted morc than $30 \mathrm{~min}$. $S_{\text {s-in }}$ decayed with time, and unlike the washout of $S_{\text {out }}$, the loss of $S_{\text {sin }}$ was not prevented by use of thick-walled electrodes that produce recordings with a high series resistance. 


\section{Discussion}

We have shown that 5 -HT had multiple actions on neurons in primary embryonic cell cultures of mouse hippocampus and striatum. The most commonly observed response was a potassium conductance increase, similar to a response seen in hippocampal slices (Jahnsen, 1980; Segal, 1980; Andrade et al., 1986; Colino and Halliwell, 1987), as well as other parts of the brain (VanderMaelen, 1985). We have shown that this response exhibited inward rectification and washed out. Two other responses to 5-HT were observed less often in both hippocampal and striatal neurons. $S_{\text {t-in }}$ may be due to the opening of a channel that permits both sodium and potassium ions to pass, and possibly calcium ions as well. This response desensitized, but did not wash out. $S_{\text {s-in }}$ was also the result of a conductance increase. Without reversing this response, we cannot say to what extent this conductance increase was selective for sodium, calcium, or potassium.

Methysergide, a 5-HT antagonist previously found to block the 5-HT-activated potassium conductance in hippocampal neurons (Segal, 1980), failed to block $S_{\text {out }}$ in this study in both hippocampal and striatal neurons. In contrast, we found methysergide produced a current similar to $S_{\text {out }}$ in both hippocampal and striatal neurons. Since high doses of methysergide produced smaller responses than 5-HT, but did not inhibit 5-HT responses to any extent (Fig. $2 C$ ), it seems likely that methysergide has a low affinity for the $S_{\text {out }}$ receptor. Davies and Tongroach (1978), who were studying the 5-HT-induced suppression of firing in the striatum, found that the prolonged application of methysergide (in the absence of 5-HT) also suppressed neuronal firing. Using physiological and pharmacological criteria, Aghajanian (1981) has classified the 5-HT receptors mediating the inhibitory postsynaptic response that was activated by 5-MeODMT (but less effectively than 5-HT) as S3. 5-MeODMT activated $S_{\text {out }}$ in both hippocampal and striatal neurons without activating $S_{\mathrm{f} \text {-in }}$ in hippocampal and striatal neurons or $S_{s-\text { in }}$ in hippocampal and striatal neurons. $S_{\text {out }}$ is thus similar to the $\mathrm{S} 3$ inhibitory postsynaptic response.

5-HT receptors-termed 5- $\mathrm{HT}_{1 \mathrm{a}}, 5-\mathrm{HT}_{1 \mathrm{~b}}$, and 5-HT - refer to receptors selectively activated by $8-\mathrm{OH}-\mathrm{DPAT}, \mathrm{CPP}$, and MPP, respectively (Peroutka, 1985; Sills et al., 1984; Lyon et al., 1986). Andrade et al. (1986) found that 8-OH-DPAT mimicked the action of 5-HT by activating a potassium conductance in rat hippocampal slices, and that this response was blocked by spiperone. On this evidence, they suggested that the 5-HTactivated potassium conductance was mediated by the $5-\mathrm{HT}_{1 \mathrm{a}}$ receptor. However, we did not find that $8-\mathrm{OH}-\mathrm{DPAT}$ activated $\mathrm{S}_{\text {out }}$ in the cultured hippocampal and striatal neurons. This implies either that $S_{\text {out }}$ in mouse hippocampal and striatal neurons is not mediated by the $5-\mathrm{HT}_{\mathrm{Ia}}$ receptors or that there are differences in the pharmacology of $\mathrm{S}_{\text {out }}$ when mouse neurons are maintained in primary culture.

In contrast to the action of methysergide at $S_{\text {oul }}$, methysergide was an antagonist of $S_{\text {s-in }}$. Using physiological and pharmacological criteria, Aghajanian (1981) has classified the 5-HT receptors mediating this slow, methysergide-sensitive, excitatory response as $\mathrm{S} 1 . \mathrm{S}_{\mathrm{f} \text {-in }}$ has been more difficult to categorize pharmacologically. Metoclopramide and $d$-tubocurarine were found to block $S_{\text {f-in }}$ completely and reversibly in hippocampal neurons. Neither metoclopramide nor $d$-tubocurarine have previously been reported to block central 5-HT responses. $d$-Tubocurarine has previously been shown to block similar 5-HT responses in rabbit nodose ganglia (Higashi and Nishi, 1982) and Aplysia neurons (Gerschenfeld and Paupardin-Tritsch, 1974).

$\mathrm{S}_{\text {out }}$ was the result of an increased potassium conductance. The reversal potential of this response was eq al to the potassium reversal potential calculated from the 1 ernst equation, and it changed in the predicted way followin changes in the external concentration of potassium ions. The current-voltage curve of $\mathrm{S}_{\text {out }}$ shows that the conductance change of the response was voltage dependent, decreasing when the membrane potential was raised above $-55 \mathrm{mV}$. This inward rectification can be explained in a number of different ways. 5-HT might fail to open the potassium channels at depolarized potentials, or the 5-HT gated potassium channels may open in response to a depolarizing voltage in the absence of 5-HT. The recent discovery of magnesium block of the inward rectifier channel (Matsuda et al., 1987; Vandenberg, 1987) may also explain the voltage dependence of $\mathrm{S}_{\text {out }}$.

Washout of $S_{\text {out }}$ suggests that this response is dependent upon cytoplasmic factors. Recent work by Andrade et al. (1986) indicated that a similar response to 5-HT in hippocampal slice pyramidal neurons was mediated by a GTP-binding protein (Gilman, 1984). Trussell and Jackson (1986, 1987) found that the washout of a similar adenosine-activated potassium conductance was prevented by the addition of $100 \mu \mathrm{M}$ GTP to the patch electrode filling solution, and on the basis of additional experiments with pertussis toxin and GTP analogs, they concluded that a GTP-binding protein mediated the adenosineactivated potassium conductance. Thus, $S_{\text {out }}$ seen here is probably mediated by a GTP-binding protein, and its washout is most likely due to loss of GTP by diffusion. GTP-binding proteins have also been implicated in morphine- and clonidineactivated potassium conductances in locus coeruleus neurons (Aghajanian and Wang, 1986).

The similarity between $S_{\text {out }}$ and the adenosine-activated potassium conductance in striatal neurons (Trussell and Jackson, 1985 ) is consistent with the hypothesis that 5-HT and adenosine are activating the same potassium channel through a common biochemical mechanism. The nonadditivity of baclofen and 5-HT responses suggests that this is the case for the responses to these 2 compounds in pyramidal neurons in hippocampal slices (Andrade ct al., 1986). Other nonadditivity experiments in locus coeruleus neurons suggest that opiate and $\alpha_{2}$-adrenergic receptors also may converge on the same conductance by a common biochemical mechanism (Andrade and Aghajanian, 1986; North and Williams, 1985).

The ion selectivity and voltage dependence of $S_{\text {our }}$ make this response similar to several other chemical responses in mammalian neurons, including the adenosine-activated potassium conductance in cultured striatum (Trussell and Jackson, 1985), baclofen responses in the rat hippocampus (Gahwiler and Brown, 1985; Newberry and Nicoll, 1985), and opiate and $\alpha_{2}$-adrenergic responses in the rat locus coeruleus (North and Williams, 1985). The similarities between these various responses and the nonadditivity cited above suggest that $S_{\text {out }}$ may be a member of a general class of transmitter responses in which receptor modulation of an inwardly rectifying potassium channel is mediated by a GTP-binding protein (North et al., 1987).

A fast inward current, $S_{\text {f-in }}$, was found in both hippocampal and striatal neurons. This response was similar in terms of reversal potential, voltage dependence, and desensitization to 
5-HT responses in neuroblastoma $\times$ glioma hybrid cells (Christian et al., 1978) and in rabbit nodose ganglion neurons (Higashi and Nishi, 1982). In addition, $d$-tubocurarine was also found to block the 5-HT-induced response in the nodose ganglia ( $\mathrm{Hi}-$ gashi and Nishi, 1982). While no similar response to 5-HT application has been found in a mammalian CNS preparation, dorsal raphe stimulation does evoke a rapid EPSP in striatal neurons, and it is likely that 5-HT is the transmitter (Park et al., 1982).

$S_{\text {f-in }}$ did not wash out, even when series resistances were very low. This, together with the rapid time course of the response, suggests a direct coupling between the receptor and a channel, without mediation by cytoplasmic factors or a second messenger. Whereas cytoplasmic constituents probably are not essential for the coupling between receptor and channel of $S_{\text {f-in }}$, these experiments do not permit any conclusions concerning the possibility of some form of regulation of the response by the cytoplasm.

$S_{f-i n}$ appears to have many of the characteristics of a classic excitatory synaptic receptor exemplified by the nicotinic ACh receptor of vertebrate skeletal muscle (Steinbach, 1980). The response is rapid and the channel conducts both sodium and potassium. The response desensitizes strongly, and the desensitization may be biphasic (Feltz and Trautmann, 1982).

$\mathrm{S}_{\mathrm{s}-\mathrm{in}}$, a slow excitatory response, was also observed in both hippocampal and striatal neurons, but its incidence in striatum was significantly higher than in hippocampus. Because of the low frequency of occurrence of this response in cultures from both brain regions, its rapid disappearance, and the fact that this response was usually accompanicd by a relatively small conductance increase (approximately 10\%), we can say little about the ionic mechanism of this response. As previously mentioned, 5-HT has been reported to activate adenylate cyclase, and $S_{5-i n}$ may be a result of the 5-HT activation of adenylate cyclase. $S_{s-i n}$ was similar to the responses produced by the adenylate cyclase activators, forskolin, norepinephrine, and dopamine. Responses to these adenylate cyclase activators were observed more frequently than $\mathrm{S}_{\mathrm{s} \text {-in }}$, and were larger in magnitude.

With high series resistance recordings, $S_{\text {s-in }}$ disappeared, but $S_{\text {out }}$ did not. Thus, while we are confident that $S_{\text {out }}$ depends on cytoplasmic components, we cannot reach a similar conclusion for $\mathrm{S}_{\mathrm{s} \text {-in }}$. The loss of $\mathrm{S}_{\mathrm{s} \text {-in }}$ could have many explanations, including a very slow rate of desensitization. Since high-resistance patch electrodes preserve $S_{\text {out }}$, it would appear that maintaining diffusible cytoplasmic components in the cell was not sufficient to maintain $\mathrm{S}_{\mathrm{s} \text {-in }}$.

We have observed no significant differences in the responses to 5-HT between cultures of these 2 regions, except for the frequency of observing $S_{\text {s-in }}$, and the sensitivity of $S_{\text {out }}$ to high doses of metoclopramide. The higher incidence of $S_{\text {s-in }}$ in striatal cultures may reflect an intrinsic property of striatal neurons. As previously mentioned, both the striatum and hippocampus are innervated by serotonergic neurons (Graybiel and Ragsdale, 1979; Walaas, 1983). The cultures used in this study are deprived of their normal afferents and thus should not have any serotonergic neurons. Serotonergic neurons may have a profound influence on the expression of the different types of receptors. It should be quite interesting to restore various inputs to these cell cultures and then reexamine the 5-HT responses.

\section{References}

Adams, P. R., and M. Galvan (1986) Voltage-dependent currents of vertebrate neurons and their role in membrane excitability. Adv. Neurul. 44: 137-170.

Aghajanian, G. K. (1981) The modulatory role of serotonin at multiple receptors in brain. In Serotonin Neurotransmission and Behavior, B. L. Jacobs and A. Gelperin, eds., pp. 156-185, MIT Press, Cambridge, MA.

Aghajanian, G. K., and J. M. Lakoski (1984) Hyperpolarization of serotonergic neurons by serotonin and LSD: Studies in brain slices showing increased $\mathrm{K}^{+}$conductance. Brain Res. 305: 181-185.

Aghajanian, G. K., and Y.-Y. Wang (1986) Pertussis toxin blocks the outward currents evoked by opiate and $\alpha_{2}$-agonists in locus coeruleus neurons. Brain Res. 371: 390-394.

Andén, N.-E., A. Carlsson, A. Dahlström, K. Fuxe, N.- $\Lambda$. Hillarp, and K. Larsson (1964) Demonstration and mapping out of nigro-neostriatal dopamine neurons. Life Sci. 3: 523-530.

Andrade, R., and G. K. Aghajanian (1986) Opiate- and $\alpha_{2}$-adrenoceptor-induced hyperpolarizations of locus coeruleus neurons in brain slices: Reversal by cyclic adenosine $3^{\prime}: 5^{\prime}$-monophosphate analogues. J. Neurosci. 5: 2359-2364.

Andrade, R., R. C. Malenka, and R. A. Nicoll (1986) A G binding protein couples serotonin and $\mathrm{GABA}_{\mathrm{b}}$ receptors to the same channels in hippocampus. Science 243: 1261-1265.

Azmitia, E. C., and M. Segal (1978) An autoradiographic analysis of the differential ascending projections of the dorsal and median raphe nuclei in the rat. J. Comp. Neurol. 179: 641-668.

Bevan, P., C. M. Bradshaw, and E. Szabadi (1975) Effects of desipramine on neuronal responses to dopamine, noradrenaline, 5-hydroxytryptamine and acetylcholine in the caudate nucleus of the rat. $\mathrm{Br}$. J. Pharmacol. 54: 285-293.

Byerly, L., and S. Hagiwara (1982) Calcium currents in internally perfused nerve cell bodies of Limnea stagnalis. J. Physiol. (Lond.) 322: 503-528.

Christian, C. N., P. G. Nelson, P. Bullock, D. Mullinax, and M. Nirenberg (1978) Pharmacologic responses of cells of a neuroblastoma X glioma hybrid clone and modulation of synapses between hybrid cells and mouse myotubes. Brain Res. 147: 261-276.

Colina, A., and J. V. Halliwell (1987) Differential modulation of three separate K-conductances in hippocampal CAl neurons by serotonin. Nature 328: 73-77.

Cottrell, G. A., and K. A. Green (1982) Responses of mouse spinal neurones in culture to locally applied serotonin. J. Physiol. (Lond.) 325: 25P-26P.

Dahlström, A., and K. Fuxe (1964) Evidence for the existence of monoamine-containing neurons in the central nervous system. I. Demonstration of monoamines in cell bodies of brain stem neurons. Acta Physiol. Scand. 62(Suppl. 232): 1-55.

Davies, J., and P. Tongroach (1978) Neuropharmacological studies on the nigro-striatal and raphe-striatal system in the rat. Eur. J. Pharmacol. 51: $91-100$.

deMontigny, C., and G. K. Aghajanian (1977) Preferential action on 5-methoxytryptamine and 5-methoxydimethyltryptamine on presynaptic serotonin receptors: A comparative iontophoretic study with LSD and serotonin. Neuropharmacology 16: 811-818.

Enna, S. J., J. P. Bennett, Jr., D. B. Bylund, I. Creese, D. R. Burt, M. E. Charness, H. I. Yamamura, R. Simantov, and S. H. Snyder (1977) Neurotransmitter receptor binding: Regional distribution in human brain. J. Neurochem. 28: 233-236.

Feltz, A., and A. Trautmann (1982) Desensitization at the frog neuromuscular junction: A biphasic process. J. Physiol. (Lond.) 322:257272.

Fozard, J. R., and A. T. M. Mobarok Ali (1978) Blockade of neuronal tryptamine receptors by metoclopramide. Eur. J. Pharmacol. 49: 109112.

Gahwiler, B. H., and D. A. Brown (1985) GABA $_{B}$-receptor-activated $\mathrm{K}^{+}$current in voltage-clamped $\mathrm{CA}_{3}$ pyramidal cells in hippocampal cultures. Proc. Natl. $\Lambda$ cad. Sci. USA 82: 1558-1562.

Gerschenfeld, H. M., and D. Paupardin-Tritsch (1974) On the transmitter function of 5-hydroxytryptamine at excitatory and inhibitory monosynaptic junctions. J. Physiol. (Lond.) 243: 457-481. 
Gilman, A. G. (1984) G proteins and dual control of adenylate cyclase. Cell 36: 577-579.

Graybiel, A. M., and C. W. Ragsdale (1979) Fiber connections of the basal ganglia. In Development and Chemical Specificity of Neurons, M. Cuenod, G. W. Kreutzberg, and F. E. Bloom, eds., pp. 239-283, Elsevier, Amsterdam.

Hamill, O. P., A. Marty, E. Neher, B. Sakmann, and F. J. Sigworth (1981) Improved patch-clamp techniques for high-resolution current recording from cells and cell-free membrane patches. Pfluegers Arch. 391: 85-100.

Herz, A., and W. Zieglgänsberger (1968) The influence of microelectrophoretically applied biogenic amines, cholinomimetics and procaine on synaptic excitation in the corpus striatum. Int. J. Neuropharmacol. 7: 221-230.

Higashi, H., and S. Nishi (1982) 5-Hydroxytryptamine receptors of visceral primary afferent neurones on rabbit nodose ganglia. J. Physiol. (Lond.) 323: 543-567.

Jackson, M. B., P. Leveille, R. Fisher, and L. Attardo (1988) Neurophysiological development in primary cell culture. In Developmental Neurophysiology, P. Kellaway, ed., John Hopkins Press, Baltimore, $\mathrm{MD}$.

Jahnsen, H. (1980) The action of 5-hydroxytryptamine on neuronal membranes and synaptic transmission in area CAl of the hippocampus in vitro. Brain Res. 197: 83-94.

Leysen, J. E. (1985) Characterization of serotonin receptor binding sites. In Neuropharmacology of Serotonin, A. R. Green, ed., pp. 79116, Oxford U.P., Oxford.

Lyon, R. A., M. Titeler, J. D. McKenney, P. S. Magee, and R. A. Glennon (1986) Synthesis and evaluation of phenyl- and benzoylpiperazines as potential serotonergic agents. J. Med. Chem. 29: 630634.

Marty, A., and E. Neher (1983) Tight-seal whole-cell recording. In Single-Channel Recording, B. Sakmann and E. Neher, eds., pp. 107121 , Plenum, New York.

Matsuda, H., A. Saigusa, and H. Irisawa (1987) Ohmic conductance through the inwardly rectifying $\mathbf{K}$ channel and blocking by internal $\mathrm{Mg}^{2+}$. Nature 325: 156-159.

Mosko, S. S., and B. L. Jacobs (1977) Electrophysiological evidence against negative neuronal feedback from the forebrain controlling midbrain unit activity. Brain Res. 119: 291-303.

Nestler, E. J., and P. Greengard (1984) In Protein Phosphorylation in the Nervous System, E. J. Nestler and P. Greengard, eds., Wiley, New York.

Newberry, N. R., and R. A. Nicoll (1985) Comparison of the action of baclofen with $\gamma$-aminobutyric acid on rat hippocampal pyramidal cells. J. Physiol. (Lond.) 360:161-185.

North, R. A., and J. T. Williams (1985) On the potassium conductance increased by opioids in rat locus coeruleus neurones. J. Physiol. (Lond.) 364: 265-280.

North, R. A., J. T. Williams, A. Surprenant, and M. J. Christie (1987) $\mu$ and $\delta$ receptors belong to a family of receptors that are coupled to potassium channels. Proc. Natl. Acad. Sci. USA 84: 5487-5491.

Panula, P., L. Rechardt, and H. Hervonen (1979) Ultrastructure of cultured rat neostriatum. Neuroscience 4: 1441-1452.

Park, M. R., J. A. Gonzales-Vegas, and S. I. Kitai (1982) Serotonergic excitation from dorsal raphe stimulation recorded intracellularly from rat caudate-putamen. Brain Res. 243: 49-58.

Peacock, J. H., D. F. Rush, and L. H. Mathers (1979) Morphology of dissociated hippocampal cultures from fetal mice. Brain Res. 169: 231-246.

Peroutka, S. J. (1985) Selective labeling of 5- $\mathrm{HT}_{1 \mathrm{a}}$ and $5-\mathrm{HT}_{16}$ binding sites in bovine brain. Brain Res. 344: 167-171.

Peroutka, S. J., and S. H. Snyder (1981) Two distinct serotonin receptors: Regional variations in receptor binding in mammalian brain. Brain Res. 208: 339-347.
Premont, J., M.-C. Daguet-de Montety, A. Herbet, J. Glowinski, J. Bockaert, and A. Prochiantz (1983) Biogenic amines and adenosinesensitive adenylate cyclases in primary cultures of striatal neurons. Dev. Brain Res. 9: 53-61

Rogawski, M. A., and G. K. Aghajanian (1980) Norepinephrine and serotonin: Opposite effects on the activity of lateral geniculate neurons cvoked by optic pathway stimulation. Exp. Neurol. 69:678-694.

Seamon, K. B., W. Padgett, and J. W. Daly (1981) Forskolin: Unique diterpene activator of adenylate cyclase in membranes and in intact cells. Proc. Natl. Acad. Sci. USA 78: 3363-3367.

Segal, M. (1980) The action of serotonin in the rat hippocampal slice preparation. J. Physiol. (Lond.) 303: 423-439.

Sills, M. A., B. B. Wolfe, and A. Frazer (1984) Determination of selective and nonselective compounds for the $5-\mathrm{HT}_{\text {Ia }}$ and $5-\mathrm{HT}_{1 \mathrm{~b}}$ receptor subtypes in rat frontal cortex. J. Pharmacol. Exp. Ther. 231: 480-487.

Steinbach, J. H. (1980) Activation of nicotinic acetylcholine receptors. In The Cell Surface and Neuronal Function, C. W. Cotman, G. Poste, and G. L. Nicolson, eds., pp. 119-156, Elsevier/North-Holland, New York.

Steinbusch, H. W. M. (1981) Distribution of serotonin-immunoreactivity in the central nervous system of the rat-cell bodies and terminals. Neuroscience 6: 557-618.

Steinbusch, H. W. M., and R. Nieuwenhuys (1979) Serolonergic neuron systems in the brain of the lamprey (Lampetra fluviatilis). Anat. Rec. 193: 693-694.

Steinbusch, H. W. M., R. Nieuwenhuys, A. A. J. Verhofstad, and D. van der Kooy (1981) The nucleus raphe dorsalis of the rat and its projection upon the caudatoputamen: A combined cytoarchitectonic, immunohistochemical and retrograde transport study. J. Physiol. (Paris) 77: 157-174

Swaiman, K. F., F. A. Neale, S. C. Fitzgerald, and P. G. Nelson (1982) A method for large-scale production of mouse brain cortical cultures. Dev. Brain Res. 3: 361-369.

Trussell, L. O., and M. B. Jackson (1985) Adenosine-activated potassium conductance in cultured striatal neurons. Proc. Natl. Acad. Sci. USA 82: 4857-4861.

Trussell, L. O., and M. B. Jackson (1986) A GTP-binding prolein mediates an adenosine-activated $\mathrm{K}^{+}$current independently of cAMP. Soc. Neurosci. Abstr, 12: 15.

Trussell, L. O., and M. B. Jackson (1987) Dependence of an adenosineactivated potassium current on a GTP-binding protein in mammalian central neurons. J. Neurosci. 7: 3306-3316.

Tsien, R. Y. (1980) New calcium indicators and buffers with high selectivity against magnesium and protons: Design, synthesis, and properties of prototype structures. Biochemistry 19: 2396-2404.

Vandenberg, C. A. (1987) Inward rectification of a potassium channel in cardiac ventricular cells depends on internal magnesium ions. Proc. Natl. Acad. Sci. USA 84: 2560-2564.

VanderMaelen, C. P. (1985) Serotonin. In Neurotransmitter Actions in the Vertebrate Nervous System, M. A. Rogawski and J. L. Barker, eds., pp. 201-240, Plenum, New York.

VanderMaelen, C. P., and G. K. Aghajanian (1982) Serotonin-induced depolarization of rat facial motoneurons in vivo: Comparison with amino acid transmitters. Brain Res. 239: 139-152.

Walaas, I. (1983) The hippocampus. In Chemical Neuroanatomy, P. C. Emson, ed., pp. 337-358, Raven Press, New York.

Wiklund, L., L. Léger, and M. Persson (1981) Monoamine cell distribution in the cat brain stem. A fluorescence histochemical study with quantification of indolaminergic and locus coeruleus cell groups. J. Comp. Neurol. 203: 613-647.

Yakel, J. L., L. O. Trussell, and M. B. Jackson (1986) Serotonergic responses in cultured mouse striatal neurons. Soc. Neurosci. Abstr. 12: 726 . 